\title{
Tatiana Bragante
}

MEDIDAS RELATIVAS DAS ESTRUTURAS

QUE COMPÕEM A ARTICULAÇÃO

METACARPOFALANGEANA EM EQÜINOS

São Paulo 


\section{Tatiana Bragante}

\section{Medidas relativas das estruturas que compõem a articulação metacarpofalangeana em eqüinos}

Dissertação apresentada ao Programa de Pósgraduação em Anatomia dos Animais Domésticos e Silvestres da Faculdade de Medicina Veterinária e Zootecnia da Universidade de São Paulo para a obtenção do titulo de Mestre em Ciências

Departamento:

Cirurgia

Área de concentração:

Anatomia dos Animais Domésticos e Silvestres

Orientador:

Prof. Dr. André Luis do Valle De Zoppa 
Autorizo a reprodução parcial ou total desta obra, para fins acadêmicos, desde que citada a fonte.

DADOS INTERNACIONAIS DE CATALOGAÇÃO-NA-PUBLICAÇÃO

(Biblioteca Virginie Buff D’Ápice da Faculdade de Medicina Veterinária e Zootecnia da Universidade de São Paulo)

$$
\text { T.1685 }
$$

Bragante, Tatiana

Medidas relativas das estruturas que compõem a articulação metacarpofalangeana em eqüinos / Tatiana Bragante.- São Paulo: T. Bragante, 2006.

$77 \mathrm{f}$ : : il.

Dissertação (mestrado) - Universidade de São Paulo. Faculdade de Medicina Veterinária e Zootecnia. Departamento de Cirurgia, 2006.

Programa de Pós-graduação: Anatomia dos Animais Domésticos e Silvestres.

Área de concentração: Anatomia dos Animais Domésticos e Silvestres.

Orientador: Prof. Dr. André Luis do Valle De Zoppa.

1. Articulação metacarpofalangeana em eqüinos. 2.Qualidade preditiva. 3. Tendões e ligamentos articulares. 4. Padronização da espessura e da largura das estruturas. I. Título. 


\section{UNIVERSIDADE DE SÃO PAULO \\ Faculdade de Medicina Veterinária e Zootecnia \\ Comissão de Bioética}

\section{PARECER}

Interessado: Tatiana Bragante

Assunto: Protocolo de experimentação adotado em experimento animal.

A Comissão de Bioética da Faculdade de Medicina Veterinária e Zootecnia da Universidade de São Paulo, após analisar o projeto sob o número 812/2005, intitulado: "Medidas relativas das estruturas que envolvem a articulação metacarpofalangeana em eqüinos", no qual foram utilizados 17 (dezesete) pares de membros torácicos de eqüino (peças de matadouro), sob responsabilidade do Prof. Dr. André Luis do Valle De Zoppa, constatou que o mesmo foi realizado de acordo com os princípios de bioética, adotados por esta Comissão.

São Paulc, 30 de novembro de 2005

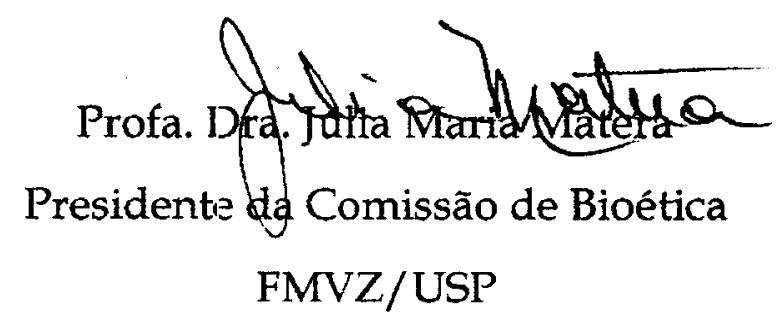




\section{FOLHA DE AVALIAÇÃO}

Nome: BRAGANTE, Tatiana

Titulo: Medidas relativas das estruturas que compõem a articulação metacarpofalangeana em eqüinos

Dissertação apresentada ao Programa de Pósgraduação em Anatomia dos Animais Domésticos e Silvestres da Faculdade de Medicina Veterinária e Zootecnia da Universidade de São Paulo para a obtenção do titulo de Mestre em Ciências

Data:

1

\section{Banca Examinadora}

Prof. Dr. Instituição:

Assinatura: Julgamento:

Prof. Dr. Instituição:

Assinatura: Julgamento:

Prof. Dr. Instituição:

Assinatura: Julgamento: 


\section{DEDICATÓRIA}

Aos animais, todos eles, todas as espécies, tamanhos, formas. Dedicar qualquer trabalho a vocês é o mínimo que posso fazer depois de tudo o que fizeram para me ensinar.

Mas especialmente a Terry, Shanaia e Genuine. Desculpe pelos momentos de ausência.

Onde estiverem... Obrigada. 


\section{AGRADECIMENTO}

\section{Uma criança pronta para nascer perguntou a Deus:}

- Dizem-me que serei enviado a Terra amanfã... Como viverei lá, sendo assim pequeno e

$$
\text { indefeso? }
$$

E Deus disse: - Entre muitos anjos, eu escolhi um especial para você. Estará The esperando e tomará conta de você.

Mas diga-me: aqui no Céu eu não faço nada a não ser cantar e sorrir, o que é suficiente para que eu seja feliz. Serei feliz lá?

Seu anjo cantará e sorrirá para você... A cada dia, a cada instante, você sentirá o amor do seu anjo e será feliz.

Como poderei entender quando falarem comigo, se eu não conheço a língua que as pessoas

$$
\text { falam? }
$$

Com muita paciência e carinho, seu anjo The ensinará a falar.

E o que farei quando eu quiser Te falar?

Seu anjo juntará suas mãos e the ensinará a rezar.

Eu ouvi que na Terra há homens maus. Quem me protegerá?

Seu anjo The defenderá mesmo que signifique arriscar sua própria vida.

Mas eu serei sempre triste porque eu não Te verei mais.

Seu anjo sempre the falará sobre Mim, The ensinará a maneira de vir a Mim, e Eu estarei sempre dentro de você.

Nesse momento havia muita paz no Céu, mas as vozes da Terra já podiam ser ouvidas. $\mathcal{A}$ criança, apressada, pediu suavemente: Oh Deus, se eu estiver a ponto de ir agora, diga-me, por favor, o nome do meu anjo.

E Deus respondeu: - Você chamará seu anjo de... Mãe! (autor desconhecido). 


\section{AGRADECIMENTOS}

Como agradecer alguém que foi nada mais que fundamental para que eu pudesse completar, não somente essa, mas todas as fases da minha vida. Para que eu pudesse superar cada obstáculo e levantar a cada tombo. Para que eu pudesse chorar baixinho em seu ombro quentinho e seguro.

Para que eu pudesse rir e voar cada vez mais alto, já que eu sabia que você estaria ali para me segurar se eu caísse...

Como agradecer a você que antes de tudo me deu o maior presente de todos. $\mathcal{A}$ VIDA!

Mãe Obrigada. 


\section{AGRADECIMENTOS}

Pela amizade que você me vota, por meus defeitos que você nem nota, por meus valores que você aumenta, por minha fé que você alimenta...

Por esta paz que nós nos transmitimos, por este pão de amor que repartimos, pelo silêncio que diz quase tudo, por este olhar que me reprova mudo...

Pela pureza dos seus sentimentos, pela presença em todos os momentos, por ser presente, mesmo quando ausente, por ser feliz quando me vê contente, Por este olhar que diz: "Filha, vá em frente!" Por ficar triste, quando estou tristonha, por rir comigo quando estou risonha...

Por repreender-me, quando estou errada, por meu segredo, sempre bem guardado, por seu segredo, que só eu conheço, e por achar que apenas eu mereço, por me apontar pra DEUS a todo o instante, por esse amor tão constante...

Por tudo isso e muito mais eu digo: "Deus te abençoe, meu pai querido!" (autor desconhecido). 


\section{AGRADECIMENTOS}

Pai, agradecer a você seria o mínimo a fazer...

Você que sempre esteve ao meu lado, nessa e em todas as outras jornadas em que estive...

Apoiando-me, guiando, tutorando, financiando,

Com toda sua sabedoria, me fazendo entender, resmungar, obedecer, crescer...

Por todas as risadas, lágrimas, apoio, mesmo que às vezes a contragosto...

Por me ajudar a ser quem sou...

Muito obrigada. 


\section{AGRADECIMENTOS}

Meu бeбê, meu bibelô, minha jóia mais valiosa...

Que sejam minhas suas dores, seus desesperos, suas fraquezas...

Que eu represente a você o que representas a mim...

Meu porto seguro, meu tesouro, parte integrante da minha existência...

Tem em minha vida o lugar de maior destaque. Amo-te incondicionalmente.

A você, minha irmã querida, minha Luciana “... sorriso de menina por onde passar...".

Obrigada 


\section{AGRADECIMENTOS}

“Pudera eu ter o dom de um poeta ou de um músico...

Para poder colocar em verso e melodia o sentimento de uma amizade.

Amigo ocupa mais espaço do que o lado esquerdo do peito...

Amigo é aquele com quem choro... É aquele com quem rio...

Amigo é um só não importa se tenho um ou cem. Cada um... Em cada momento...

É especial... É único, é vital...!

Amigo não se escolhe...

Não se "pede" ninguém em amizade... Ela existe ou não, sem tempo prédeterminado, sem prazo pra iniciar.

Amizade é sentimento é, afeto, amor, respeito, veracidade, troca, carinho, cumplicidade, é um beijo... (autor desconhecido)

Durante a jornada pessoas se tornaram parte do meu cotidiano, mas algumas se tornaram especiais, sendo elas os funcionários da anatomia que me acolheram com tanto carinho e respeito, os funcionários do Serviço de Cirurgia de Grandes Animais, que sempre me deram um apoio indescritivel.

Rodrigo Cruz, Renata Rossetti, Carolina Penna, Alexandra Mac'Darby, Thais Sodré, Alexandre Tabet, Rodrigo Romero, Marcio Ferreira, Rodrigo Crispim, obrigada por terem me dado à oportunidade de chamá-los de amigos. 
AGRADECIMENTOS

Thais Machado, Isaac Albuquerque, David Vtirizaga, Juliana Plácido Guimarães, Carla Casagrande, Daniele Scandalora, Família Talon espero ter vocês em minha vida para todo o sempre. Obrigada por tudo.

Aos amigos de uma vida toda, Fábio Iared, Adriana Caroprezo Morini, Patrícia Mathias Guglielmi, Ana Claudia Daldon, Thais de Azevedo Finazzi, Allan Lockley e suas respectivas famílias, sem vocês eu não poderia me considerar completa, plena. Só posso agradecer e pedir para que vocês não saiam da minha vida nunca. 


\section{AGRADECIMENTOS}

Aos professores Luis Cláudio Lopes Corrêa da Silva, Raquel Yvonne Baccarin, Aline De Zoppa, Wilson Roberto Fernandes pelo carinho com o qual me acolheram. Ao professor André Luis do Valle De Zoppa, por ter aceito me orientar, por me ensinar, me apoiar e principalmente ter se tornado um amigo querido.

Ao professor Thiago Luis de Salles Gomes, por ter sido meu mentor, tutor, idealizador e por principalmente ter me acolfido como uma amiga e por ter acreditado em mim e na minha paixão pela profissão e pelos animais.

A todos, só posso agradecer e compartilhar a realização e mérito dessa obra. 


\section{AGRADECIMENTOS}

"Uma pessoa é gigante quando se interessa pela sua vida, quando busca alternativas para o seu crescimento, quando sonha junto com você" (William

$$
\text { Shakespeare) }
$$

A professora Maria Angélica Miglino por jamais desistir de me ensinar não somente a fazer ciência, mas a me ensinar a ser acima de tudo um ser fumano melhor. Obrigada por ter me mostrado o verdadeiro valor de uma amizade, por mais que eu não tenha demonstrado merecimento para tal.

Por tudo o que me proporcionou...

Por tudo o que me ensinou...

Por ter me ensinado a ter garra e perseverança...

O meu muito OBRIGADA. 
AGRADECIMENTOS

Ao senhor Valmir Tunala e ao frigorífico Pomar, pela atenção e por ceder às peças utilizadas nesse estudo. 
"¿́, mas tenho ainda muita coisa para arrumar, promessas que me fiz e que ainda não cumpri

Palavras me aguardam tempo exato para falar

Coisas minhas talvez você nem queira ouvir,

Já sei othar o rio por onde a vida passa, sem me precipitar e nem perder a hora.

Escuto um silêncio que há em mim e basta, outro tempo começou para mim agora"

(Ana Carolina e Totonho Villeroy) 


\section{RESUMO}

BRAGANTE, T. Medidas relativas das estruturas que compõem a articulação metacarpofalangeana em eqüinos. [Relative measures of the structures that composes the metacarpophalangeal joint in horses]. 2006. $79 \mathrm{f}$. Dissertação (Mestrado em Ciências) - Faculdade de Medicina Veterinária e Zootecnia, Universidade de São Paulo, São Paulo, 2006.

Visou-se neste estudo criar uma forma de qualidade preditiva, buscando uma padronização das estruturas que compõem a articulação metacarpofalangeana, através do método de corte pós-congelamento e mensuração das estruturas nas medidas de espessura e largura. Então através da análise estatística foi possível gerar esse padrão para as seguintes estruturas: tendão flexor digital superficial, tendão flexor digital profundo, cápsula articular, ligamento extensor, ligamento intersesamoideo e ainda correlacionar os valores obtidos, visando agora à interligação de estruturas em seu estado de normalidade, para que pudesse ser aplicado em situações de injúrias. Dentro das estruturas analisadas a que mais apresentou variações foi a cápsula articular, talvez pela falta de padronização no momento da coleta (idade, função, histórico clínico). No caso da correlação não foi possível chegar a valores significativos, uma vez que a correlação apresentou-se baixa para a maioria das estruturas.

Palavras-Chaves: Articulação metacarpofalangeana em eqüinos. Qualidade preditiva. Tendões e ligamentos articulares. Padronização da espessura e da largura das estruturas 


\begin{abstract}
BRAGANTE, T. Relative measures of the structures that compose the metacarpophalangeal joint in horses. [Medidas relativas das estruturas que compõem a articulação metacarpofalangeana em eqüinos]. 2006. $79 \mathrm{f}$. Dissertação (Mestrado em Ciências) - Faculdade de Medicina Veterinária e Zootecnia, Universidade de São Paulo, São Paulo, 2006.
\end{abstract}

This study, try to create a predicative quality, looking for a pattern for the structures that compose the metacarpophalangeal joint, using the method of cutting after freezing and making the measures of the structures in denseness and largeness. Then through the statistics analysis it was possible to create the pattern to the following structures: superficial digital flexor tendon, deep digital flexor tendon, articular capsule, extensor ligaments, intersesamoids ligaments and still make the correlation with the numbers that was found, trying to get the interconnect of the structures in the normal position, to be used in injuries situations. The articular capsule was the structure that shows the highest variation, maybe because there was not a pattern at the moment of collecting (age, function, clinical historical). In the correlation it was not possible to find significant values, once the correlation was low to the majority of structures.

Key words: Metacarpophalangeal joint in horses. Predicative quality. Tendons and ligaments from the fetlock joint. Pattern to the structures that compose the metacarpophalangeal joint. 


\section{LISTA DE ABREVIATURAS E SÍMBOLOS}

SUPCP: $\quad$ Tendão Flexor Digital Superficial, na mensuração de largura.

SUPLG: $\quad$ Tendão Flexor Digital Superficial, na mensuração de espessura.

PROFCP: $\quad$ Tendão Flexor Digital Profundo, mensuração de largura.

PROFLG: $\quad$ Tendão Flexor Digital Profundo, mensuração de espessura.

CAPFR: $\quad$ Cápsula articular, porção plantar.

CAPTR: Cápsula articular, porção palmar.

EXTEDIRCP: Ligamento Extensor direito, mensuração de largura (porção proximal).

EXTEDIRLG: Ligamento Extensor direito, mensuração de espessura (porção proximal).

EXTESQCP: Ligamento Extensor esquerdo, mensuração de largura (porção proximal).

EXTESQLG: Ligamento Extensor esquerdo, mensuração de espessura (porção proximal).

INTERCP: $\quad$ Ligamento Intersesamóideo, mensuração de largura.

INTERLG: $\quad$ Ligamento Intersesamóideo, mensuração de espessura.

EXTCP: Ligamento Extensor, mensuração de largura (porção distal).

EXTLG: $\quad$ Ligamento Extensor, mensuração de espessura (porção distal).

TFDS: $\quad$ Tendão Flexor Digital Superficial.

B: $\quad$ Firma registrada.

N: $\quad$ Número de Observações.

DP: Desvio Padrão.

CV: $\quad$ Coeficiente de Variação. 
MIN: $\quad$ Mínimo.

MAX: Máximo.

GL: $\quad$ Grau de Liberdade.

FV: $\quad$ Fontes de Variação.

Int: Interação. 


\section{LISTA DE FIGURAS}

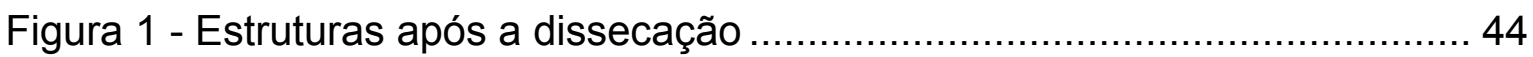

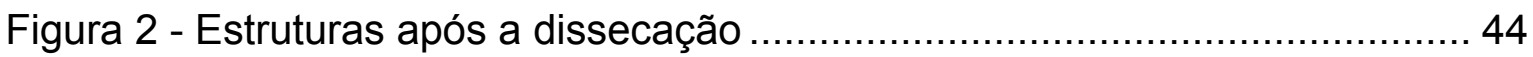

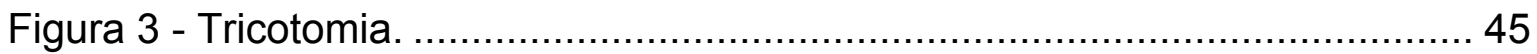

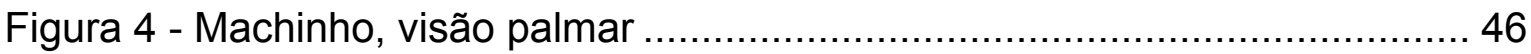

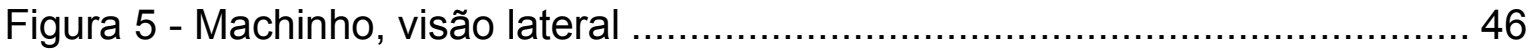

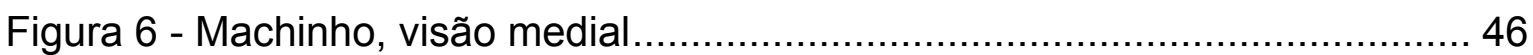

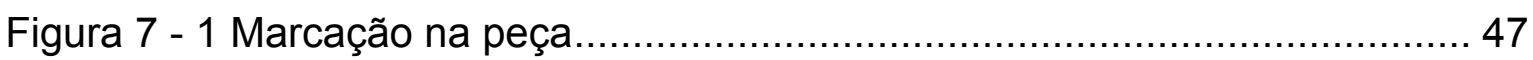

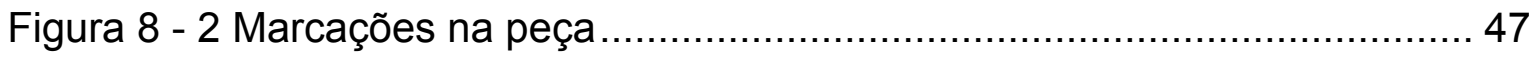

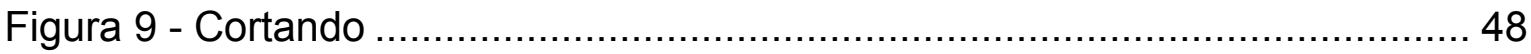

Figura 10 - Porção proximal, pós corte ……………............................................. 48

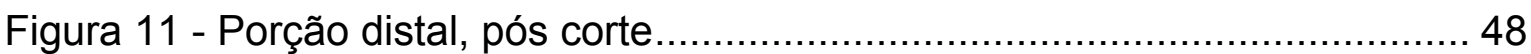

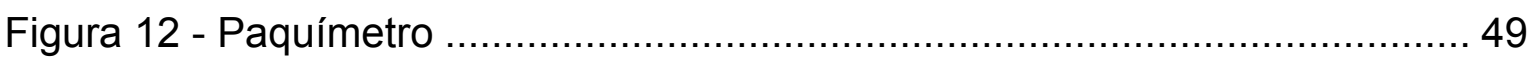

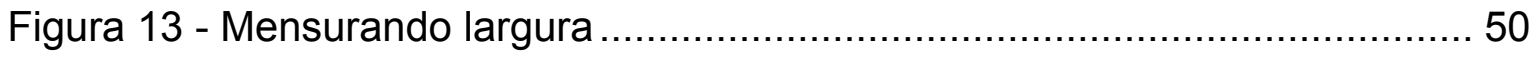

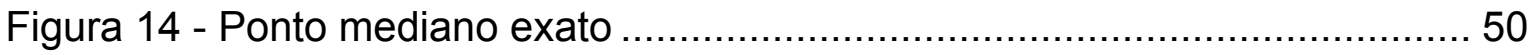

Figura 15 - Mensurando espessura.................................................................... 50

Figura 16 - Ponto mediano exato do terceiro metacarpiano................................. 51

Figura 17 - Mensurando espessura cápsula ……………………................. 51 


\section{LISTA DE GRÁFICOS}

Gráfico 1 - Valores de normalidade para a variável SUPCP ...............................54

Gráfico 2 - Valores de normalidade para a variável PROFLG............................. 54

Gráfico 3 - Valores de normalidade para a variável PROFCP.............................. 55

Gráfico 4 - Valores de normalidade para a variável CAPFR ................................ 55

Gráfico 5 - Valores de normalidade para a variável CAPTR …………………....56

Gráfico 6 - Valores de normalidade para a variável INTERLG ........................... 56

Gráfico 7 - Valores de normalidade para a variável INTERCP ............................ 57

Gráfico 8 - Valores de normalidade para a variável EXTESQLG ......................... 57

Gráfico 9 - Valores de normalidade para a variável EXTESQCP ..........................58

Gráfico 10 - Valores de normalidade para a variável EXTEDIRLG ..................... 58

Gráfico 11 - Valores de normalidade para a variável EXTEDIRCP ......................59

Gráfico 12 - Valores de normalidade para a variável EXTLG.............................. 59

Gráfico 13 - Valores de normalidade para a variável EXTCP................................6 60

Gráfico 14 - Estatísticas descritivas gerais para as estruturas avaliadas .............60

Gráfico 15 - Estimativa de médias e desvios padrões....................................... 62

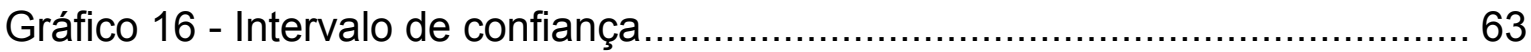




\section{SUMÁRIO}

1 INTRODUÇÃO

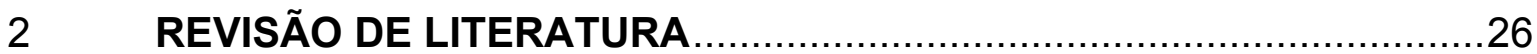

2.1 ANATOMIA

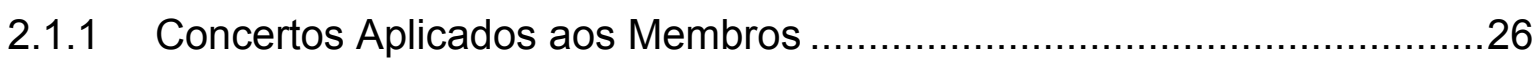

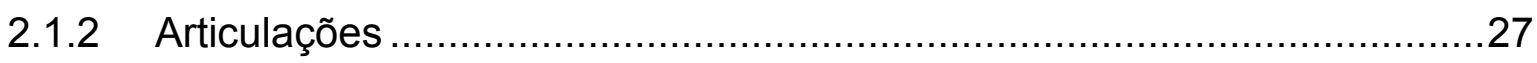

2.1.3 Classificação das Articulações Sinoviais .............................................300

2.1.3.1 Articuações em Relação aos Tipos de Movimentos .................................32

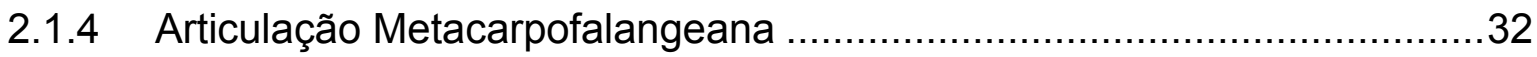

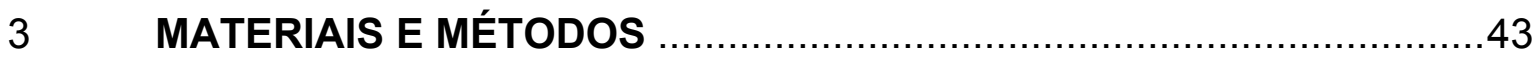

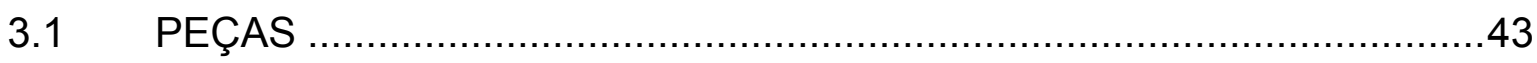

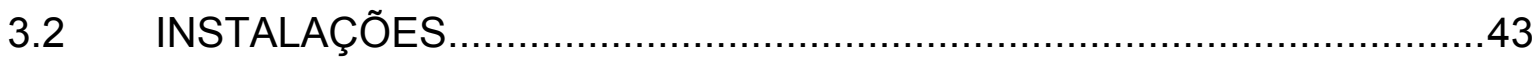

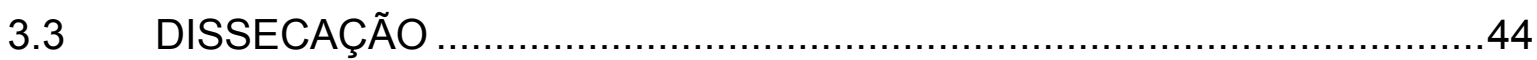

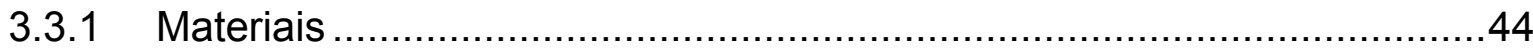

3.4 PREPARAÇÃO DAS PEÇAS PARA A COLETA DE DADOS …................45

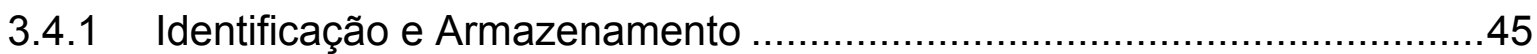

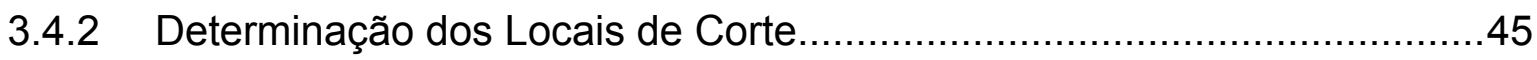

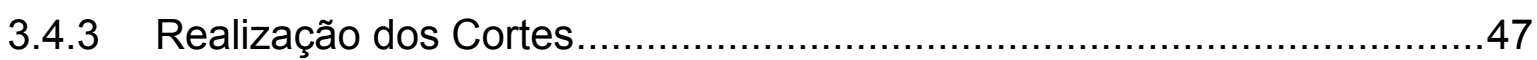

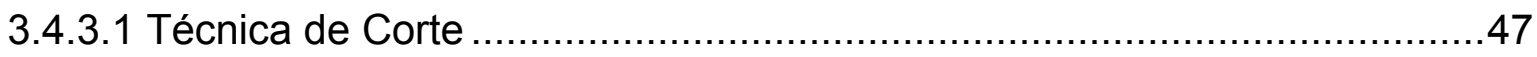

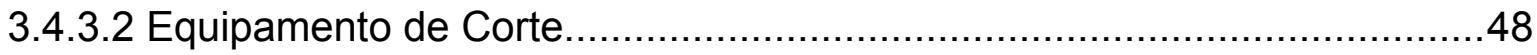

3.4.4 Mensuração das Estruturas Vizualizadas ………................................49

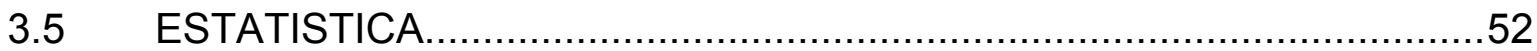

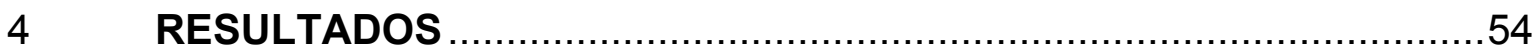

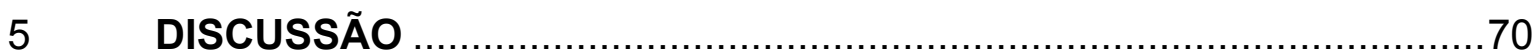

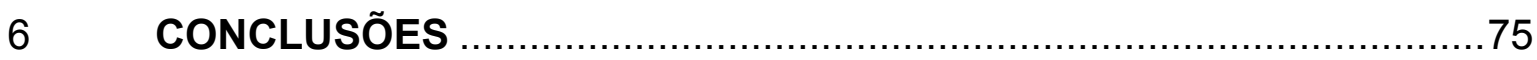

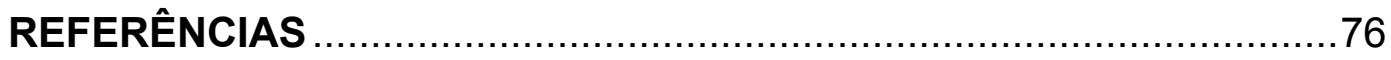




\section{INTRODUÇÃO}

Os eqüinos, a partir de sua domesticação, passaram a ter participação fundamental e decisiva no destino da humanidade. Uma vez incorporados à sociedade, se tornaram indispensáveis para o desenvolvimento da mesma, devido principalmente à sua capacidade locomotora. Até meados de 1839 esses animais eram para os homens o meio de transporte mais rápido (RIEMERSMA, 1986).

Baseados nesse panorama, Bogert (1989) e Fraccaroli (1977), colocaram que dentre todos os fenômenos apresentados pelos seres vivos, nenhum outro é de tamanha importância e complexidade quanto aos movimentos, já que, para que aconteçam, deve existir integração e atuação de diversas forças no sistema músculo-esquelético, dentre elas, a muscular, a gravitacional e a inércia. Após a atuação dessas forças e o comando do sistema nervoso central, tem-se a transformação de energia química em energia mecânica, resultando no movimento configurado no espaço do gesto motor, onde a análise e avaliação de seus aspectos anátomo-fisiológicos e mecânicos deve ser feita com precisão (FRACCAROLI, 1977).

Com o desenvolvimento da fotografia no século dezenove criou-se a possibilidade de captação e pós-visualização de movimentos rápidos, melhorando as análises e avaliações dos gestos motores, estimulando em diversos pesquisadores o interesse pela biomecânica eqüina, resultando na realização de inúmeros estudos, dos diferentes aspectos do sistema locomotor dos animais desta espécie, principalmente pelo fato desses animais ainda representarem para a sociedade um fator econômico e militar de suma importância (BOGERT, 1989; MUYBRIDGE, 1957). 
As guerras e as conquistas tiveram as marcas das patas do cavalo, a posse dos eqüinos passou a significar nobreza e poder (BOGERT, 1989; MUYBRIDGE, 1957). Após essa época, devido a múltiplos fatores, a quantidade de estudos voltados para essa área teve um considerável declínio, voltando a apresentar um aumento no início dos anos setenta com a revalorização desses animais, principalmente nos esportes e como uso de modelo para novas técnicas experimentais relacionadas ao sistema locomotor. Com o desenvolvimento da tecnologia, a análise locomotora se tornou muito mais precisa (BOGERT, 1989).

Uma vez que todas as leis mecânicas de Newton podem ter aplicações no comportamento do sistema locomotor dos animais que possuem posição quadrupedal, principalmente na análise quantitativa dos movimentos e forças que ocorrem no sistema músculo-esquelético, se reconheceu que essas forças poderiam ter um papel importante na etiologia da claudicação. Com a viabilização de tecnologias de custos acessíveis, determinadas análises biomecânicas passaram a ser rotineiras, tendo como pontos de interesse a distribuição das forças nos membros, o relacionamento entre essas forças e o teste padrão do movimento (BOGERT, 1989). As forças gravitacionais, inércia e musculares combinadas produzem forças muito grandes, principalmente nas articulações, como por exemplo, 2.4 vezes mais o peso corpóreo ao caminhar, chegando até a 4.9 vezes mais o peso corpóreo ao trotar (BOGERT, 1989).

Carga de forças elevadas, principalmente de complexas forças de torção, tem ligação direta com injúrias no sistema locomotor dos eqüinos. Sendo exemplos de injurias as rupturas de tendões ou ligamentos, fraturas, degenerações articulares como citaram Bogert (1989) e Ross e Dyson (2003). 
Considerando que o movimento correto será aquele que, não prejudique o organismo, o movimento não deve criar sobrecargas funcionais ou condições que levem a injúrias a curto ou longo prazo. Assim o movimento deve ser efetuado da maneira mais eficiente e gastando o mínimo de energia possível (FRACCAROLI, 1977).

Em uma situação de injúria, encontramos um movimento ineficiente e com gasto exacerbado de energia, levando a questionar tudo o que essa situação mostra como, por exemplo, determinar se a injúria ocorreu devido ao mau posicionamento do membro no momento de efetuar o movimento, ou se já vinha ocorrendo, mas se mostrou clinicamente apenas em determinado momento. Ou ainda se foi conseqüência de movimentos repetidos por um determinado período de tempo (FRACCAROLI, 1977).

Segundo Ross e Dyson (2003), podemos caracterizar em 3 tipos a grande maioria das injúrias encontradas na articulação metacarpofalangeana: lesão por repetição, fragmentos articulares que possam ser removidos e fraturas sérias.

Dentro do sistema articular dos eqüinos, a articulação metacarpofalangeana é a mais afetada devido talvez, por ser a primeira dentro da seqüência de contato com o solo com alto grau de mobilidade e por estar mais sujeita a inúmeras variações de forças de pressão e tração. As injúrias nesta área articular podem evoluir para queda no rendimento, aumento nas possibilidades de traumas subseqüentes e principalmente desconforto para 0 animal. Todos estes fatos levaram essa articulação a ser o foco deste estudo. 


\section{REVISÃO DE LITERATURA}

A descrição anatomo-clínico-cirúrgica desta articulação se tornou de suma importância na rotina dos médicos veterinários que militam com a espécie eqüina.

\subsection{ANATOMIA}

A descrição anatômica da articulação metacarpofalangeana é de importância absoluta para as inúmeras situações clínico-cirúrgicas encontradas nas aplicações rotineiras do médico veterinário.

\subsubsection{Conceitos Aplicados aos Membros}

A nomenclatura utilizada para delimitar as porções e projeções dos membros é diferente da utilizada para delimitar as porções e projeções do restante do corpo do animal (DYCE; SACK; WENSING, 2004; KÖNIG; LIEBICH, 2002).

A anatomia dos membros dos eqüinos, em especial a porção distal, a qual recebe a denominação de dígito, já foi precisamente descrita e ilustrada por inúmeros autores tanto em livros como em outras formas de referências (BRADLEY, 1920; DYCE; SACK; WENSING; 1997; 2004; GETTY, 1986; KÖNIG; LIEBICH, 2002; NICKEL et al., 1986; ROSS; DYSON, 2003; SCHALLER, 1999). 
Nos membros, as estruturas que se apresentam mais próximas da junção com o corpo recebem a denominação de proximais e as estruturas que mais se afastam da junção com o corpo, recebem a denominação de distais. Uma outra convenção da nomenclatura é de determinar porção distal, o segmento dos ossos do carpo ao casco. Nesse segmento, as estruturas que ficam na direção cranial (utilizando as convenções da nomenclatura utilizada para o restante do corpo) são denominadas de dorsais, e as que ficam na direção caudal (também utilizando as convenções de nomenclatura utilizadas para o corpo) são denominadas de palmares nos membros torácicos e plantares nos membros pélvicos (DYCE; SACK; WENSING, 2004).

\subsubsection{Articulações}

Segundo König e Liebich (2002), o estudo das articulações recebe o nome de Artrologia.

Os ossos encontram-se uns com os outros nas articulações, algumas são destinadas a unir firmemente os ossos enquanto outras permitem livre movimento. O grau de mobilidade de dois ossos, ou de suas respectivas cartilagens, que se posicionam um ao lado do outro, depende fundamentalmente de como é a estrutura do local intermediário e de onde esses elementos estão conectando-se. As articulações podem ser subdivididas conforme sua função, preenchimento e grau de mobilidade (DYCE; SACK; WENSING; 2004; KÖNIG; LIEBICH 2002). 
Segundo Dyce, Sack e Wensing (2004) e König e Liebich (2002) elas podem ser classificadas como citado a seguir:

Articulações fibrosas: Os ossos são unidos por tecido conjuntivo denso; a maioria ocorre no crânio, sendo conhecida como suturas. Antigamente eram conhecidas como sinartroses, exatamente por essa característica de quase imobilidade. A ligação de um dente ao osso de seu alvéolo pode ser incluída nessa categoria sob o nome de gonfose.

Articulações cartilaginosas: Os ossos estão ligados por cartilagem; a maioria é conhecida como sincondroses (como as articulações fibrosas, também eram denominadas antigamente de sinartroses). Estas compreendem as articulações entre as epífises e diáfises dos ossos longos dos animais jovens e as articulações correspondentes da base do crânio.

Articulações sinoviais: Pode-se chamar de articulação verdadeira, aquela que possui o desenvolvimento de uma cartilagem articular e fluido articular em seu interior. "Uma cavidade preenchida por líquido se interpõe entre os ossos"; Conhecidas como diartroses (DYCE; SACK; WENSING, 2004; KÖNIG; LIEBICH, 2002).

As articulações diferenciam-se quanto ao número de ossos, o grau de movimento, ou ainda, quanto à forma de suas superfícies articulares (KÖNIG; LIEBICH, 2002).

As articulações repetem-se em princípio, em seu plano básico de formação, apesar de suas diferenças marcantes. As principais articulações são mantidas por ligamentos intracapsulares, capsulares e/ou extracapsulares. Algumas articulações mantêm a estrutura de união sob forma de cartilagem fibrosa, que se igualam as superfícies articulares incongruentes servindo para a 
estabilização da articulação. Além disso, porções de tecido adiposo intracapsulares podem desempenhar a função de amortecedores (KÖNIG; LIEBICH, 2002).

Segundo Dyce, Sack e Wensing (2004) e König e Liebich (2002), as articulações sinoviais são compostas de uma cavidade articular, superfície articular, cartilagem articular, membrana sinovial, sinóvia e cápsula articular.

A cavidade articular é o que podemos chamar de espaço repleto com líquido viscoso, cuja cor varia desde amarelo-palha a castanho-médio e que possui tanto funções lubrificantes quanto nutritivas, além de separar os ossos que se articulam. Esse líquido recebe o nome de sinóvia (DYCE; SACK; WENSING, 2004; KÖNIG; LIEBICH, 2002)

A superfície articular é a porção que se encontra revestida pela cartilagem articular, que por sua vez adere-se firmemente sobre uma fina superfície mineralizada na epífise óssea, não sendo recoberta por pericôndrio, mas sim envolvida completamente por uma cápsula articular (geralmente do tipo hialino, e é composta de uma camada externa fibrosa e resistente (estrato fibroso), e de uma lâmina interna rica em células, vasos e nervos (estrato sinovial)). Adere-se ao redor das margens das superfícies articulares como ligamentos quando bem desenvolvidos e destacados. A cartilagem acentua a curvatura do osso subjacente, quando apresenta formato côncavo, apresentase mais fina ao centro, sendo que nas convexas, apresenta-se mais espessa ao centro e mais fina nas extremidades (DYCE; SACK; WENSING, 2004; KÖNIG; LIEBICH, 2002).

Em muitas articulações dos ungulados, os limites das cartilagens articulares aprofundam-se, o que resulta na formação das fossas sinoviais. A 
textura dos feixes de fibras colágenas na matriz cartilaginosa é orientada exatamente pelo principio das forças de tração e pressão (DYCE; SACK; WENSING, 2004; KÖNIG; LIEBICH, 2002).

A matriz da cartilagem hialina apresenta função semelhante a um amortecedor, sendo, deformável, elástica, translúcida, de aspecto vítreo e, embora seja em geral branca com tons azuis ou róseos nos animais jovens, torna-se amarelada com a idade. A cartilagem articular é insensível e avascular (DYCE; SACK; WENSING, 2004; KÖNIG; LIEBICH, 2002).

Como complemento do revestimento da articulação encontra-se a membrana sinovial, que é uma lâmina de delicado tecido conjuntivo, vai de róseo a branco-amarelada reluzente, apresentando vilosidades sinoviais ou pregas sinoviais, as quais se diferenciam em número, tamanho, forma e distribuição dentro da articulação. Esta se adere em torno da periferia das superfícies articulares, que ficam revestidas por finas camadas de cartilagem (DYCE; SACK; WENSING, 2004; KÖNIG; LIEBICH, 2002).

Na maioria das articulações sinoviais, a membrana sinovial é reforçada externamente por uma cápsula fibrosa e faixas fibrosas adicionais (ligamentos) que ficam estrategicamente dispostas, de maneira a unir os ossos e restringir o movimento às direções e extensões exigidas, sendo vascular e sensível (DYCE; SACK; WENSING, 2004; KÖNIG; LIEBICH, 2002).

\subsubsection{Classificação das Articulações Sinoviais}

Podem ser classificadas com critérios numéricos e geométricos (DYCE; SACK; WENSING, 1997, 2004; KÖNIG; LIEBICH, 2002; NICKEL et al., 1986). 
O sistema numérico distingue articulações simples que apresentam apenas dois ossos envolvidos, ou seja, possui apenas um par de superfícies articulares. São articulações compostas as que apresentam mais de dois ossos envolvidos, ou seja, mais de duas superfícies em oposição estão envolvidas e o movimento ocorre em mais de um nível dentro da cápsula compartilhada (DYCE; SACK; WENSING, 2004; NICKEL et al., 1986).

Utilizando o sistema geométrico, podemos classificar as articulações sinoviais de diversas maneiras, segundo Dyce, Sack e Wensing, (2004); König e Liebich, (2002) e Nickel et al. (1986):

- Articulação Plana: Apresentam pequenas superfícies articulares que, à primeira vista, parecem planas (na verdade, as superfícies articulares são sempre curvas) ex: Articulação entre as vértebras.

- Articulação Dobradiça (Gínglimo): possui uma superfície articular com formato semelhante a um segmento de cilindro e outra escavada para recebê-la. O movimento pendular é possível apenas em um plano, ex: Articulação metacarpofalangeana.

- Articulação em Pivô (articulação trocóide): Compreende uma cavilha encaixada em um anel (articulação radioulnar proximal).

- Articulação Condilar: Formada por dois côndilos com formato de soqueira que se encaixam nas superfícies côncavas correspondentes. EX: Articulação femorotibial.

- Articulação Elipsóide: Apresenta uma superfície convexa ovóide que se ajusta em uma concavidade correspondente. EX: Articulação radiocárpica. 
- Articulação em Sela (articulação selar): Combina duas superfícies, cada uma delas convexa ao máximo em uma direção, côncava também ao máximo em uma segunda direção em ângulo reto com a primeira. EX: Articulação interfalangeana distal do cão.

- Articulação Esferóide (articulação esférica): consiste em uma porção de esfera, cuja recepção ocorre dentro de uma concavidade correspondente, ex: Articulação do ombro humano.

\subsubsection{Articulações em Relação aos Tipos de Movimentos}

Podem ser classificadas como articulações rígidas (anfiartroses), por exemplo, a articulação sacroilíaca, de um só eixo (articulações em dobradiça e em cone), de dois eixos (articulação em sela e articulação elipsóide), ou ainda como de muitos eixos (articulação coxofemoral). (KÖNIG; LIEBICH, 2002; NICKEL et al., 1986).

\subsubsection{Articulação Metacarpofalangeana}

Nos animais determinadas regiões recebem além da nomenclatura anatômica, a nomenclatura zootécnica. A articulação metacarpofalangeana se enquadra em uma dessas regiões, sendo denominada de articulação do boleto (DYCE; SACK; WENSING, 1997; 2004; EZILIANO, 2001; GETTY, 1986; NICKEL et al., 1986; ROSS; DYSON, 2003). 
Constitui-se pela junção da extremidade distal do terceiro osso metacarpiano, com a extremidade proximal da falange proximal e os ossos sesamóides proximais em sua face palmar (DYCE; SACK; WENSING, 1997; 2004; EZILIANO, 2001; ROSS; DYSON, 2003; SCHALLER, 1999).

O terceiro osso metacarpiano, quando o animal é adulto, se apresenta fundido com o segundo e o quarto ossos metacarpianos. É conhecido como o osso da "canela", sendo mais forte e excepcionalmente mais robusto que os outros dois. Em seu corte transverso, seu formato é ovalado e sua espessura compacta (atestando sua enorme resistência) (DYCE; SACK; WENSING, 1997, 2004).

Seu único elemento funcional se encontra em sua porção distal (uma vez que sua porção proximal, juntamente com a porção proximal dos outros dois ossos serve de apoio para a articulação do carpo), apresentando um côndilo com uma quilha axial que se articula com a falange proximal e os ossos sesamóides (DYCE; SACK; WENSING, 1997, 2004; ROSS; DYSON, 2003).

A resistente falange proximal é comprimida dorso-palmarmente, sendo mais larga proximal do que distalmente. Sua extremidade proximal é côncava e aprofundada axialmente por um sulco para adaptar-se ao côndilo do terceiro osso metacárpico. Tubérculos palpáveis de cada lado recebem os ligamentos colaterais da articulação do boleto (DYCE; SACK; WENSING, 2004).

O par de ossos sesamóides proximais aumenta a concavidade da articulação do boleto; são pirâmides de três lados cujas bases se confrontam distalmente. Esses ossos sofrem fraturas mais freqüentemente do que todos os ossos dos membros torácicos (DYCE; SACK; WENSING, 2004). 
Esta articulação é classificada no sistema geométrico como gínglimo, com relação ao tipo de movimento, é classificada como articulação de muitos eixos, uma vez que possui movimentos de extensão, flexão e ligeiros movimentos de lateralidade e quanto ao sistema numérico é classificada como composta. Quando o animal se apresenta na posição de estação pode-se dizer que o animal está em estado de flexão dorsal parcial (GETTY, 1986).

Com objetivos didáticos, divide-se as funções básicas das articulações em:

- Permitir o movimento.

- Possibilitar a transferência de forças.

Biomecanicamente, as articulações devem suportar o sistema músculoesquelético e transmitir as forças resultantes dos movimentos. No momento do apoio, os ossos transmitem uma grande carga de força, e as articulações sinoviais atuam na distribuição e transferência destas forças, mantendo baixos os níveis de estresses de contato, e por impactos repetidos. A variação desta função aumenta a susceptibilidade dessas articulações sofrerem injúrias (EZILIANO, 2001).

A biomecânica do movimento em qualquer articulação envolve três planos perpendiculares de movimento de translação, médio-lateral, dorsopalmar ou plantar e próximo-distal, com a possibilidade de executar movimentos de rotação em cada plano (EZILIANO, 2001).

Estes planos de movimento sofrem restrições pela cápsula articular, ligamentos, tendões, músculos de flexão, extensão, abdução e adução, as inserções músculo-tendíneas periarticulares auxiliam 0 controle dos movimentos rotacionais. A prevenção dos movimentos fora dos limites 
fisiológicos é mantida através da oposição de forças das estruturas acima mencionadas (EZILIANO, 2001).

Segundo Dyce; Sack e Wensing (1997, 2004); Nickel et al. (1986); Ross e Dyson (2003) e Schaller (1999), a articulação metacarpofalangeana, apresenta como formas de união diversos tendões e ligamentos e ainda a cápsula articular.

A cápsula articular está inserida ao redor das margens das superfícies articulares. É ampla e espessa palmarmente, onde existe uma bolsa interposta entre ela e os tendões flexores digitais, mas estes também estão inseridos na cápsula (DYCE; SACK; WENSING, 1997, 2004; GETTY, 1986). Dessa maneira, permite a mobilidade da região além de prolongar grandes bolsas dorsal e palmar proximalmente. No interior da bolsa dorsal contém uma prega capsular que se origina na diáfise do terceiro metacárpico e projeta-se distalmente ao centro da bolsa, formando a região conhecida zootecnicamente como "machinho" (DYCE; SACK; WENSING, 1997, 2004; GETTY, 1986).

A superfície articular segundo Getty (1986), é dividida em 3 partes. Sendo elas, superfície articular da extremidade distal do terceiro osso metacarpiano, superfície articular da falange proximal, superfície articular dos ossos sesamóides proximais.

Os músculos se inserem por meio de tendões de tecido conjuntivo. Os tendões consistem quase que inteiramente de feixes de colágeno em arranjo regular e possuem grande força tênsil. Na verdade, é mais provável que a tensão excessiva rompa o ventre muscular ou destaque um fragmento de osso na inserção em vez de romper o próprio tendão (DYCE; SACK; WENSING, 1997, 2004). 
Os tendões são mais elásticos do que se supõe e são capazes de absorver e acumular energia quando estirados. Em determinadas situações, não se observa que a variação de elasticidade dos tendões representa uma contribuição substancial para a locomoção e que grande parte da atividade metabólica realizada por muitos músculos é dedicada ao estiramento dos tendões, de forma que a energia acumulada possa ser liberada mais tarde (DYCE; SACK; WENSING, 2004).

Apesar de rijos, os tendões podem ser lesados por pressão ou fricção excessiva, particularmente quando mudam de direção sobre proeminências ósseas ou sofrem desvios sobre tecidos rígidos. Uma forma de proteção que desenvolve em tais locais é a condrificação ou ossificação local (ossos sesamóides) (DYCE; SACK; WENSING, 2004).

Uma alternativa é conferida pelo desenvolvimento de coxins repletos de líquido nos locais de risco. Se apenas uma face do tendão estiver sob risco, uma bolsa pode interpor-se de um lado; se uma porção maior da circunferência estiver vulnerável, o coxim envolve o tendão em uma bainha tendinosa. As paredes dessa bolsa e bainhas e o líquido contido lembram os componentes similares das articulações sinoviais (DYCE; SACK; WENSING, 1997, 2004).

Devido principalmente a traumas, encontram-se freqüentemente rompimentos ou lacerações nos tendões flexores, especialmente no tendão do músculo flexor digital superficial e essas lesões acontecem mais na região metacarpiana e, por essa razão, observa-se uma influência na cicatrização tendínea pós-trauma (MORAES et al., 2002). 
Segundo Dyce; Sack e Wensing (1997, 2004); Getty (1986); Nickel et al., (1986); Ross e Dyson (2003) e Schaller (1999), encontramos na articulação metacarpofalangeana os seguintes tendões e ligamentos:

- Ligamentos colaterais: Conectam os ossos maiores, sendo eles o terceiro metacarpiano e a Falange Proximal, e se observa 2 em cada articulação Metacarpofalangeana.

- $\quad$ Ligamentos palmares: Tecidos condróides, que contém fibras transversas fixadas aos ossos em ungulatas, em especial proximalmente, servindo como face de apoio para os tendões flexores.

- $\quad$ Ligamentos sesamóides colaterais: Cada uma destas estruturas conecta um osso sesamóide ao metacarpo e falange proximal. São menores e triangulares. Os ligamentos mais profundos são curtos e passam para a borda próximo-palmar da falange proximal. Esta série de ligamentos assegura que tais ossos de movam diante do côndilo metacárpico em harmonia com a falange proximal. Surgem na superfície abaxial de cada osso sesamóideo, passam dorsalmente e dividem-se em dois ramos, um dos quais termina na depressão existente na extremidade distal do terceiro osso metacárpico, e o outro na eminência existente na extremidade proximal da falange proximal. Eles são parcialmente cobertos pelos ramos do ligamento sesamóideo superior.

- Ligamento metacarpointersesamoideo: Ligamento elástico dos eqüinos, com duas fixações proximais ao terceiro metacarpo, terminando no ligamento palmar; Unem os ossos sesamóides; estendem-se proximais a eles, entrando desta forma na formação da superfície articular da articulação do boleto. Esta extensão suporta os tendões quando os sesamóides deslizam 
para baixo do côndilo na hiperextensão máxima da articulação do boleto. Quando a articulação esta totalmente flexionada, os ossos sesamóides perdem o contato com o côndilo e se posicionam sobre a parte dorsal do terceiro metacarpiano, onde o contato entre os ossos é impedido pela extensão proximal do ligamento palmar.

- $\quad$ Ligamento sesamoideo reto: Sua extensão se dá a partir dos ossos sesamóides e tem sua finalização na falange média na espécie eqüina.

- $\quad$ Ligamentos sesamoideos oblíquos: Se inicia no osso sesamóide e finaliza na falange proximal. Está tanto lateral como medial ao ligamento sesamóide reto na espécie eqüina.

- $\quad$ Ligamentos sesamóides curtos: Se estende desde a borda distal de um osso sesamóide e vai até a falange proximal em ungulatas. Se encontra em ambos os lados dos ligamentos cruzados.

- $\quad$ Ligamentos cruzados: Fibras que se cruzam a partir da borda distal de um osso sesamóide até a falange proximal em ungulatas, entre os ligamentos curtos. São relativamente longos, recobrem os sesamóides e inserem-se um pouco mais distalmente e, por sua vez, são revestidos por ligamentos oblíquos que se fixam amplamente na área triangular central da superfície palmar do terceiro osso metacarpiano. Finalmente, um ligamento sesamóide reto adicional surge para conectá-los com a fibrocartilagem complementar da falange média.

Uma das razões do alto índice de injúrias na porção distal dos membros torácicos em comparação com os membros pélvicos se dá pelo fato dos membros torácicos receberem a maior parte do peso corpóreo (em média 60\%) 
(BORGES; CANOLA; MACHADO, 2001a; BORGES; CANOLA; MACHADO, 2001b).

Outra razão para esse alto índice de injúrias provém de sua própria anatomia, já que essa articulação dentre todas as articulações do sistema locomotor dos eqüinos tem a maior amplitude de movimento apresentando hiperextensão durante a fase de apoio dos membros (DENOIX et al., 1996; FERRARO, 1990; POOL; MEAGHER, 1990; PROVASI, 2001).

Durante essa fase, uma grande força é aplicada à cápsula articular e ao aparelho suspensor do boleto, ocasionando o encontro entre a região distal do terceiro metacarpiano e a região dorsopalmar da primeira falange e entre a região dorsal dos sesamóides proximais e a face palmar do terceiro metacarpiano, aumentando a susceptibilidade sabidamente existente, de afecções traumáticas, degenerativas, de apresentação aguda ou crônica (DENOIX et al., 1996; FERRARO, 1990; POOL; MEAGHER, 1990; PROVASI, 2001).

Submeter o animal a exercícios é outra maneira de verificar cargas de força exercendo influência na articulação metacarpofalangeana, já que durante sua execução suportam grandes cargas, principalmente de forças de tensão (DENOIX et al., 1996; FERRARO, 1990; POOL; MEAGHER, 1990; PROVASI, 2001).

Comprovando o alto índice de afecções encontradas nos boletos, no estudo realizado por Macoris e Bertone (2001) eles classificaram a articulação metacarpofalangeana como "difícil de obtê-la hígida", e ainda Sande (1994), colocou que claudicações associadas à articulação metacarpofalangeana representam $14 \%$ das claudicações apresentadas por eqüinos. 
Cita-se como parte das razões para esses dados o fato de que anormalidades no boleto indicam claudicação, onde também é freqüente os tecidos moles se apresentarem edemaciados e conseqüentemente reduzindo o movimento na articulação (O'BRIEN; HORNOF; MEAGHER, 1981).

Freqüentemente se faz necessário, na avaliação das claudicações em eqüinos, a utilização de métodos complementares de diagnóstico como, por exemplo, bloqueios anestésicos, exames radiográficos e ultra-sonográficos (BLEVINS; WIDMER, 1990; FERRARO, 1990; PROVASI, 2001; STASHAK, 1987).

Tanto as técnicas radiográficas, quanto às de ultra-sonografia podem ser citadas como técnicas relativamente fáceis de serem executadas, mas para que a interpretação dos resultados encontrados em qualquer uma das técnicas seja feita de forma correta é imprescindível que se conheça, a anatomia radiográfica, os sítios de inserção de tendões e ligamentos e sua aparência normal (DENOIX et al., 1996; PROVASI, 2001; WEAVER; STOVER; O'BRIEN, 1998), contudo O’Brien, Hornof e Meagher (1981) ressaltaram ainda que, para a interpretação dos exames ser mais exata e completa, é necessário fazer um exame detalhado na articulação.

A ultra-sonografia é útil para a avaliação das lesões dos tecidos moles e das articulações do boleto e do carpo no cavalo. No diagnóstico de claudicações, esta técnica foi aplicada primeiramente na avaliação de lesões dos tendões e dos ligamentos nas áreas metacárpicas e do dígito, além de poder ajudar a reconhecer lesões articulares e periarticulares, na maioria das articulações dos membros nos eqüinos (DENOIX et al., 1996). 
Durante o exame, o membro deve estar em atitude estática, pois assim o aparato suspensor e a porção palmar profunda do ligamento colateral estão tencionadas. Dorsalmente, a cápsula articular, os tendões extensores e também a porção palmar do ligamento colateral estão relaxadas. O ângulo dorsal entre a porção distal do terceiro metacarpiano e a porção proximal da primeira falange diminui quando o animal apóia o membro examinado (DENOIX et al., 1996).

Animais que tem por função, o uso da velocidade máxima, são os que mais apresentam lesões nos dígitos. Normalmente as lesões ocorrem enquanto o animal está competindo. As injurias variam desde fraturas nos sesamóides a laceração do ligamento intersesamoideo distal (BOWMAN; LEITCH; NUNAMAKER, 1984; FRETZ; BARBER; BAILEY, 1984; RICHARDSON; NUNAMAKER; SIGAFOOS, 1987; ROSS; DYSON, 2003; SOUTHWOOD; McILWRAITH, 2000).

Sinovite proliferativa crônica na articulação metacarpofalangeana é uma causa reconhecida de claudicação e queda de desempenho em cavalos de corrida. Normalmente afeta Puros Sangues jovens em treinamento (MURPHY; NIXON, 2001; ROSS; DYSON, 2003).

$\mathrm{Na}$ articulação metacarpofalangeana dos eqüinos, sinovite proliferativa crônica resulta de trauma crônico. A lesão leva vários meses para se desenvolver e é caracterizada pela proliferação sinovial no recesso da cápsula articular. Cavalos afetados normalmente claudicam após uma rigorosa sessão de treinamento. Inchaço nos tecidos moles e efusão sinovial acompanham a claudicação. A sinovite proliferativa crônica é freqüentemente acompanhada de fratura osteocondral na porção dorsal na falange proximal (STEYN et al., 1989). 
Estudos realizados sobre artroses em boletos de eqüinos mostraram que lesões articulares ou subcondrais da região palmar da porção distal final do $3^{\circ}$ osso metacarpiano se localizaram principalmente na cartilagem e próximo ao meio de cada ou dos dois côndilos e se estendendo abaxialmente (O'BRIEN; HORNOF; MEAGHER, 1981).

Segundo estudos realizados por Bramlage (1993) e Hogan et al. (1997), quando uma lesão cística se mostra clinicamente, o prognóstico se torna variável para cavalos atletas e aparenta depender de inúmeros fatores, incluindo a localização anatômica da lesão, a presença de qualquer alteração degenerativa da articulação e o tratamento adotado. 


\section{MATERIAIS E MÉTODOS}

A maneira de desenvolver a parte experimental do projeto baseou-se nos pilotos efetuados anteriormente.

\subsection{PEÇAS}

No presente trabalho foram utilizados 16 membros direitos e 14 membros esquerdos, todos torácicos, da espécie eqüina, seccionados na região da articulação cárpica, sendo que 6 dessas peças foram utilizadas para a técnica de dissecação, sendo 3 direitas e 3 esquerdas.

A diferença na quantidade de peças se deu devido à dificuldade de encontrar membros visualmente hígidos. As peças são provenientes do abatedouro e frigorífico POMAR, situado na cidade de Araguari, Minas Gerais, no abate ocorrido no dia 04 de novembro de 2004. A diferenciação entre membros direitos e membros esquerdos foi feita durante a coleta do material.

\subsection{INSTALAÇÕES}

Toda a parte experimental foi conduzida em duas dependências distintas do Departamento de Cirurgia da Faculdade de Medicina Veterinária e Zootecnia da Universidade de São Paulo - Campos de São Paulo, sendo elas:

- Prédio da Anatomia da Faculdade de Medicina Veterinária e Zootecnia da Universidade de São Paulo, sala de macroscopia. 
- Serviço de Cirurgia de Grandes Animais da Faculdade de Medicina Veterinária e Zootecnia da Universidade de São Paulo.

\subsection{DISSECAÇÃO}

Em 6 membros, visualmente hígidos, foi feita uma cuidadosa dissecação com o objetivo de identificar as estruturas que compõem a articulação metacarpofalangeana, para que no momento de avaliar as seções (cortes), houvesse a certeza da estrutura mensurada (Figuras 1 e 2).

\subsubsection{Materiais}

Para efetuar as dissecações, foi utilizado como material tricótomo lâmina de bisturi ( $\left.n^{\circ} 24\right)$, cabo de bisturi ( $\left.n^{\circ} 4\right)$, tesoura ponta romba - fina e romba romba, pinça anatômica, pinça dente de rato, pinça hemostática.

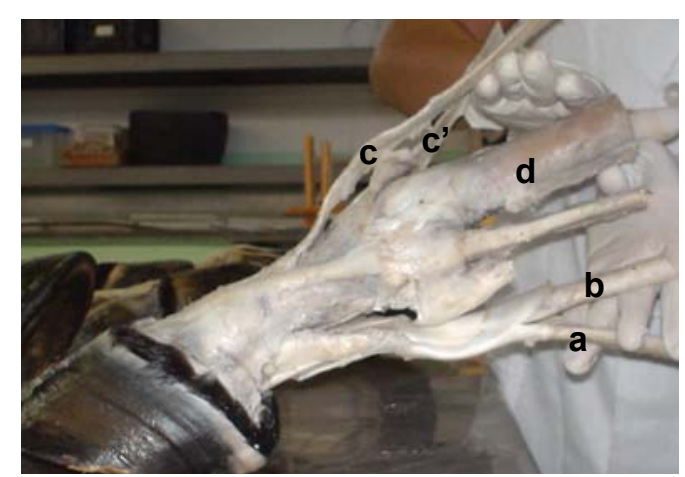

Figura 1 - Visualização das estruturas após a dissecação: (a)-Tendão Flexor Digital Profundo; (b)-Tendão Flexor Digital Superficial; (c, c')Ligamento Extensor Esquerdo e Direito respectivamente; (d) $-3^{\circ}$ metacarpiano.

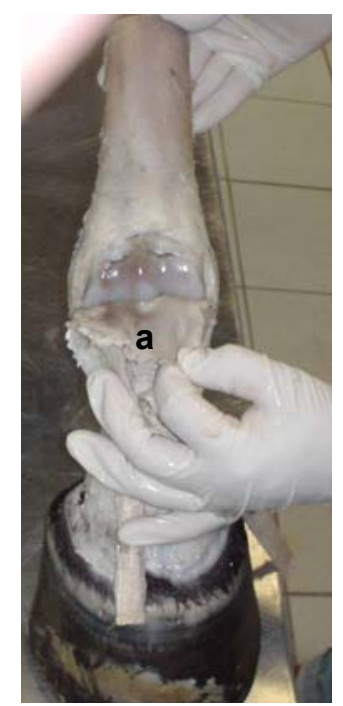

Figura 2 - Visualização das estruturas após a dissecação: (a)Cápsula Articular, porção plantar. 


\subsection{PREPARAÇÃO DAS PEÇAS PARA A COLETA DE DADOS}

A maneira padronizada de preparar as peças para a coleta de dados, gerou um aumento na confiabilidade dos dados obtidos.

\subsubsection{Identificação e Armazenamento}

Imediatamente após a coleta, as peças foram identificadas, embaladas e armazenadas a temperaturas de aproximadamente $3^{\circ} \mathrm{C}$.

Após o armazenamento em baixas temperaturas, foi efetuada uma ampla tricotomia na região do boleto (Figura 3).

Depois de efetuada a tricotomia, as peças foram congeladas onde procurou-se mantê-las em uma posição anatômica de maneira que pudesse representar o animal em estação.

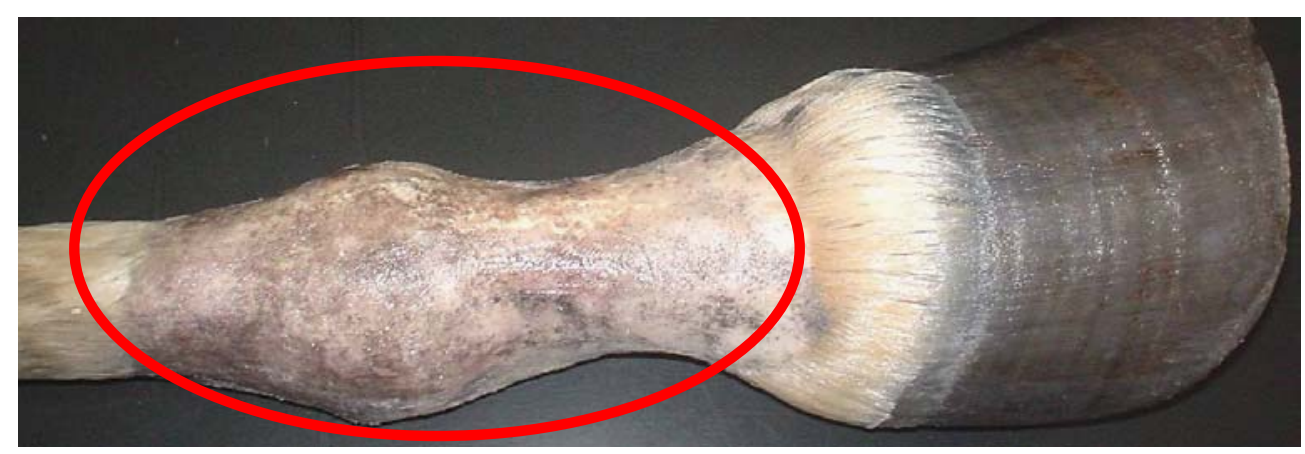

Figura 3 - Área em evidencia - Tricotomia

\subsubsection{Determinação dos Locais de Corte}

Considerou-se a porção mais distal do "machinho" que se encontra na porção palmar da articulação (Figuras 4, 5 e 6), já que essa proeminência dá a 
certeza de estar exatamente abaixo da articulação metacarpofalangeana. Com o auxílio de uma caneta esferográfica, foi feita uma marcação nessa proeminência, para que servisse de guia no momento de proceder o corte (Figura 7).

Após marcado o primeiro local de secção mensurou-se $3 \mathrm{~cm}$ acima e fez-se uma nova marcação, onde desta maneira delimitaram-se os locais de corte (Figura 8).

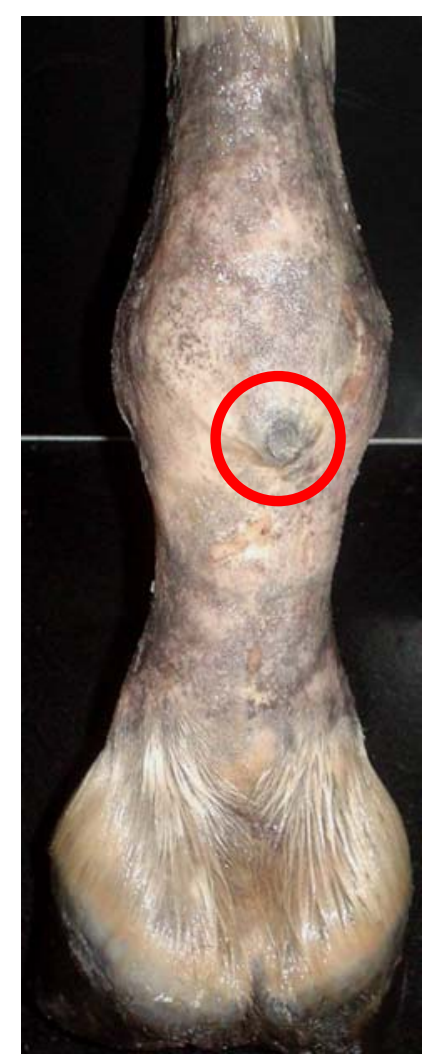

Figura 4 - Machinho visão palmar
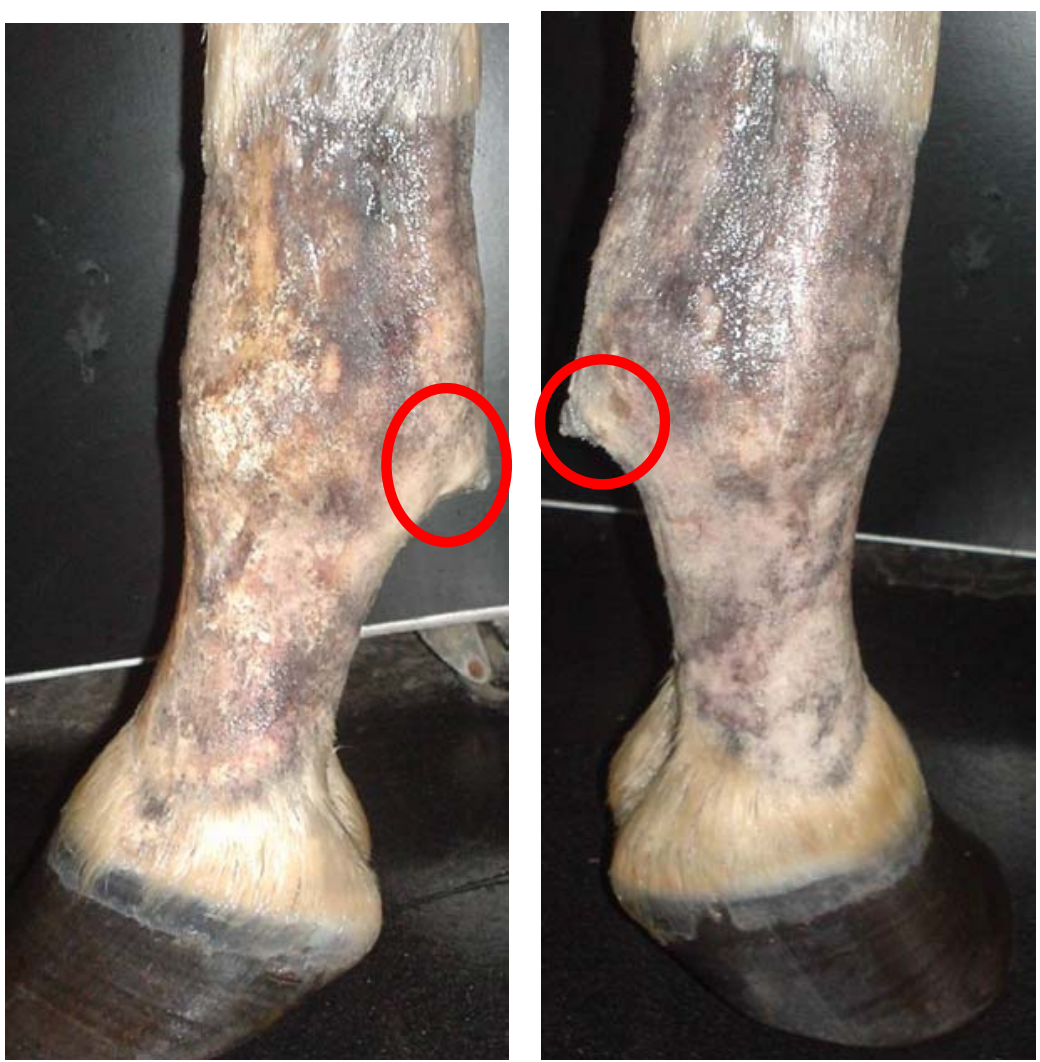

Figura 5 - Machinho - visão lateral Figura 6 - Machinho - visão medial 


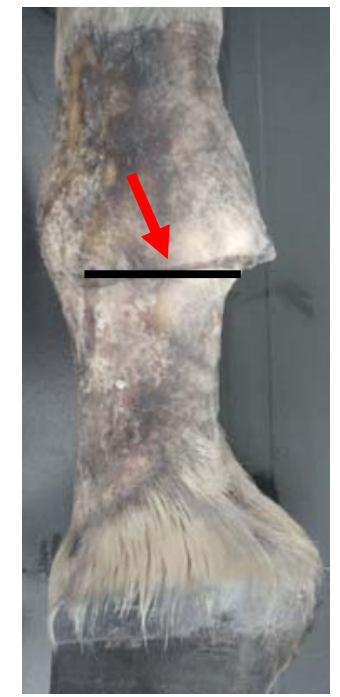

Figura 7 - 1 marcação na peça

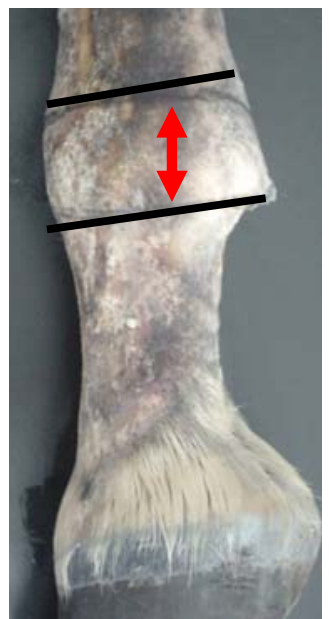

Figura 8 - 2 marcações na peça

\subsubsection{Realização dos Cortes}

A maneira de proceder aos cortes se mostrou fundamental no momento de coletar os dados.

\subsubsection{Técnica de Corte}

Depois de realizadas as marcações em cada peça, efetuou-se os cortes, que foram feitos sob o método de corte dorso palmar pós-congelamento (Figura 9), visando isolar duas superfícies articulares, sendo elas proximal e distal (Figuras 10 e 11 respectivamente). 


\subsubsection{Equipamento de Corte}

Para proceder aos cortes foi utilizada uma serra de fita da marca METVISA - Metalúrgica Visa LTDA; Modelo NC: 720; Tipo: SFGP; Fabricação:

\section{2/2005}

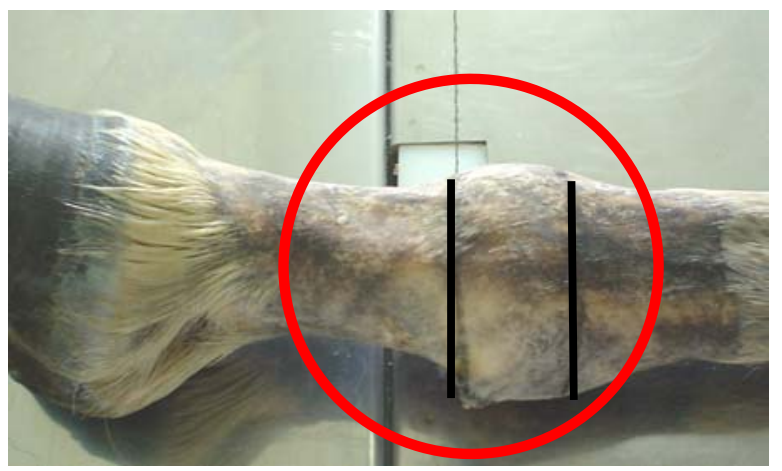

Figura 9 - Cortando: Área de corte

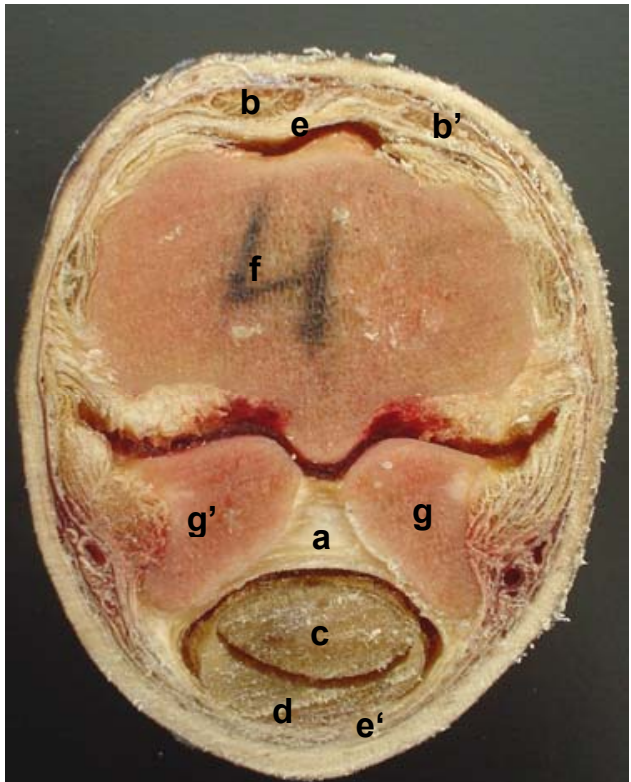

Figura 10 - Porção Proximal: (a)-Ligamento Intersesamoideo; (b, b')Ligamento Extensor Esquerdo e Direito respectivamente; (c)Tendão Flexor Digital Profundo; (d)-Tendão Flexor Digital Superficial; (e, e')-Cápsula Articular porção plantar e palmar respectivamente; metacarpiano; sesamóideos.

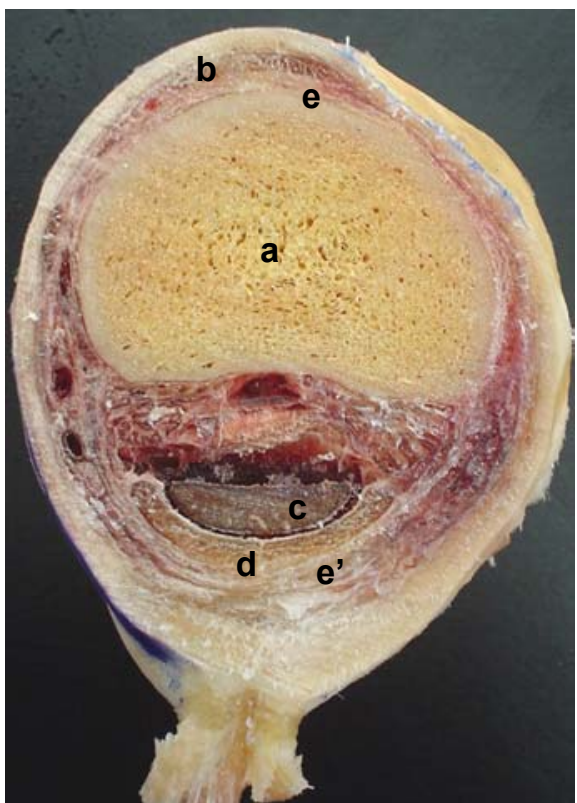

Figura 11 - Porção Distal: (a)-Falange Proximal; (b)-Ligamento Extensor; (c)-Tendão Flexor Digital Profundo; (d)-Tendão Flexor Digital Superficial; (e, e')-Cápsula Articular porção plantar e palmar respectivamente. 


\subsubsection{Mensuração das Estruturas Visualizadas}

A mensuração das estruturas foi feita com o auxilio de um paquímetro digital da marca Digemess Metrologia Dimensional ${ }^{\circledR}$, calibrado dentro das tolerâncias especificadas pelas normas internacionais pertinentes (Figura 12).

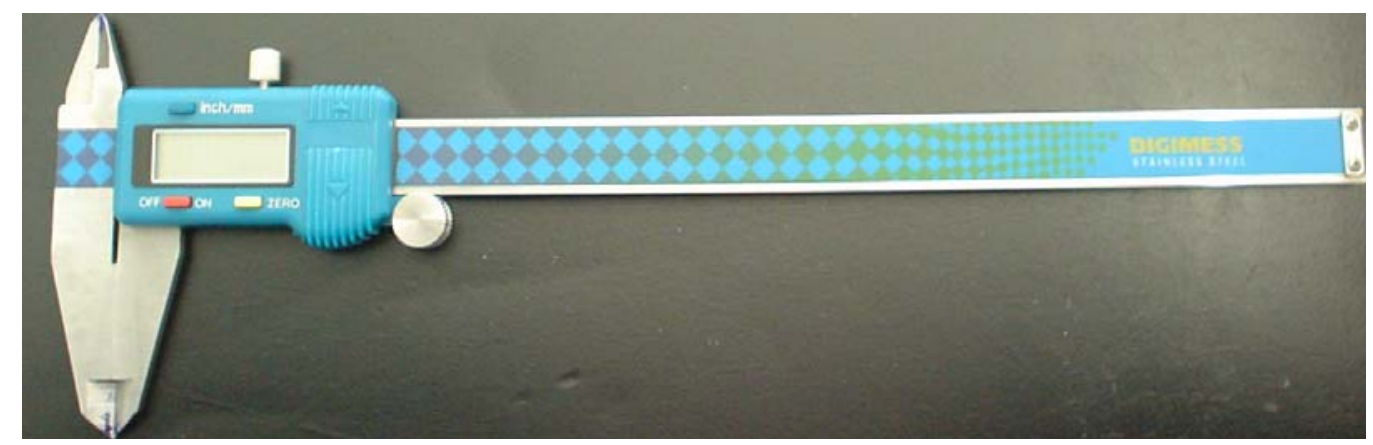

Figura 12 - Paquímetro

As estruturas mensuradas foram: o tendão flexor digital superficial, tendão flexor digital profundo, tendão extensor digital comum, tendão extensor digital lateral, ligamento intersesamoideo, cápsula articular.

Para mensurar a largura das estruturas foi posicionada uma das pontas do paquímetro na extremidade mais lateral e a outra ponta do paquímetro na extremidade mais medial, então a leitura foi feita (Figura 13). Á partir desta medida chegou-se ao ponto mediano exato, o que possibilitou a localização do ponto de mensuração da espessura (Figuras 14 e 15). 


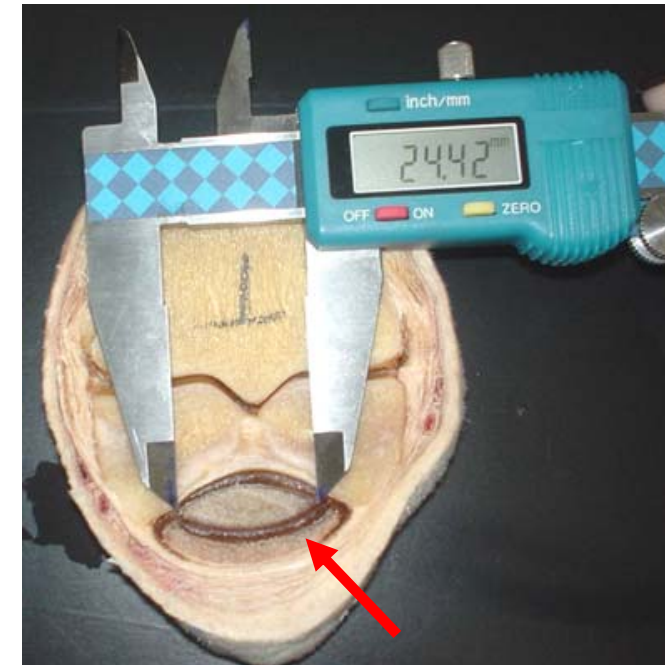

Figura 13 - Medindo Largura do Tendão Flexor Digital Profundo

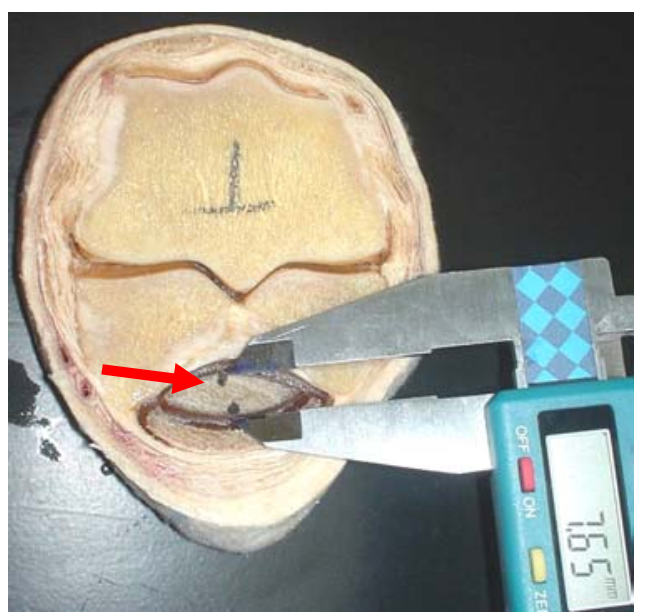

Figura 15 - Ponto de Mensuração de Espessura do Tendão Flexor Digital Profundo

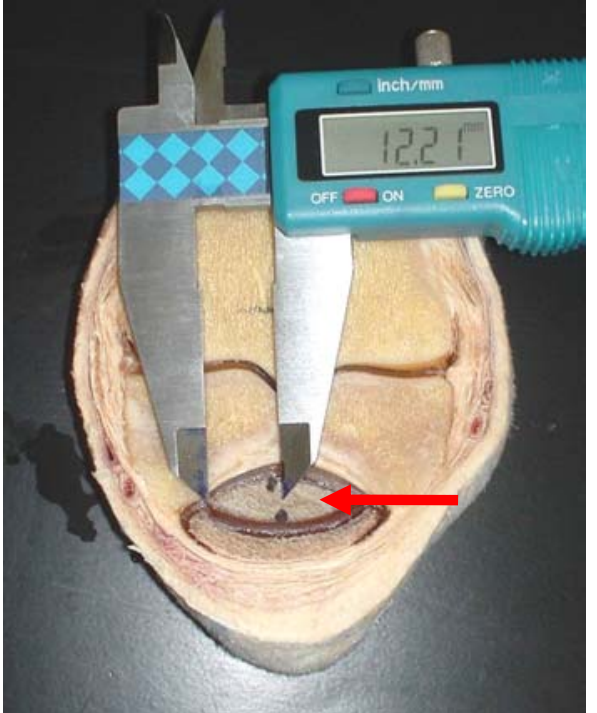

Figura14 - Ponto Mediano Exato do Tendão Flexor Digital Profundo

Esse procedimento foi adotado para todos os tendões e ligamentos mensurados, tanto na porção proximal como na porção distal.

Na cápsula articular foi feita a mensuração somente de sua espessura, procedendo da seguinte maneira:

Com base no ponto mediano exato do terceiro osso metacarpiano (Figura 16), cujo procedimento para chegar a esse ponto ocorreu da mesma maneira que para os tendões e ligamentos, seguimos até o ponto 
correspondente na cápsula e procedemos à mensuração de sua espessura (Figura 17).

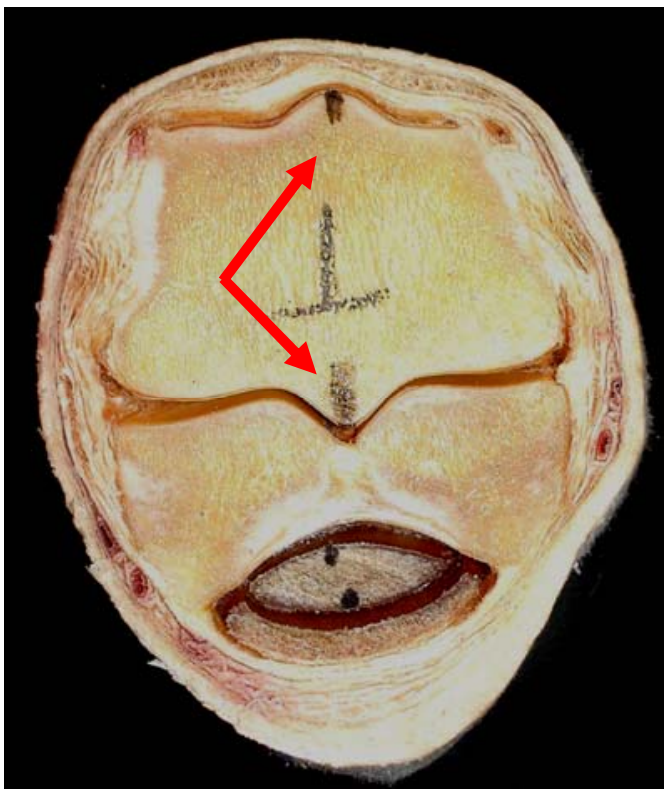

Figura16 - Ponto Mediano do $3^{\circ}$ metacarpiano

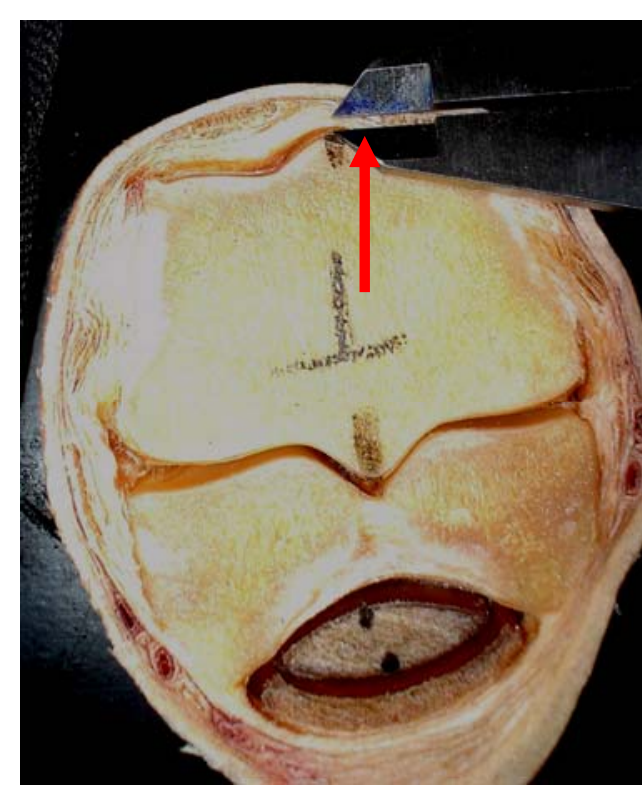

Figura17 - Mensurando Espessura da Cápsula Articular, porção palmar

Os valores encontrados foram anotados em tabelas distintas para cada porção (proximal ou distal) e para cada membro (direito ou esquerdo).

Em todas as seções, as mensurações foram feitas da parte mais superficial a parte mais profunda da articulação. 


\subsection{ESTATISTICA}

As análises estatísticas foram realizadas análises descritivas para todas as variáveis quantitativas avaliadas, visando estabelecer o padrão característico verificados nos grupos comparativos, bem como verificação das pressuposições comumente utilizadas em análises de dados experimentais. Estas análises estatísticas descritivas foram realizadas por meio de procedimento PROC UNIVARIATE do programa Statistical Analysis System, versão 9.1 .3 (SAS, 1995).

Para avaliação das variáveis quantitativas contínuas, que apresentavam as mensurações relativas ambas as porções (proximais versus distais) e os lados avaliados (direito versus esquerdo), utilizou-se, o método de quadrados mínimos, por meio do procedimento PROC GLM do programa supracitado. Nestas análises adotou-se o seguinte modelo estatístico:

$y_{i j k}=\mu+P_{i}+L_{j}+P L_{i j}+e_{i j k}$

em que,

$\mathrm{y}_{\mathrm{ijk}}=$ é o valor observado na peça $\underline{\mathrm{k}}$, do lado $\mathrm{j}$ e da porção $\underline{\mathrm{i}}$;

$\mu=$ constante inerente a todas as observações;

$P_{i}=$ efeito da i-ésima porção, sendo i = 1 (proximal) e 2 (distal);

$L_{j}=$ efeito do j-ésimo lado de avaliação, sendo j = 1 (direito) e 2(esquerdo);

$\mathrm{PL}_{\mathrm{ij}}=$ efeito da interação da porção i com o lado $\mathrm{i} ;$

$\mathrm{e}_{\mathrm{ijkl}}=$ efeito aleatório residual associado à na peça $\underline{\mathrm{k}}$, do lado j e da porção $\underline{\mathrm{i}}$;

Para avaliação das variáveis quantitativas contínuas, que apresentavam as mensurações somente em uma das porções, verificou-se o efeito dos lados 
(direitos versus esquerdo), por meio do mesmo método e procedimento, adotando-se o seguinte modelo estatístico:

$y_{i j}=\mu+L_{i}+e_{i j}$

em que,

$\mathrm{y}_{\mathrm{ij}}=$ é o valor observado na peça $\mathrm{i}$, do lado $\mathrm{i} ;$

$\mu=$ constante inerente a todas as observações;

$\mathrm{L}_{\mathrm{i}}=$ efeito do i-ésimo lado de avaliação, sendo i = 1 (direito) e 2 (esquerdo);

$\mathrm{e}_{\mathrm{ij}}=$ efeito aleatório residual associado à na peça $\mathrm{i}$, do lado $\mathrm{i} ;$

Neste trabalho foram adotados também estudos de correlação momento-produto de Pearson, por meio do procedimento PROC CORR, visando à busca de possíveis relações lineares entre as variáveis mensuradas. 


\section{RESULTADOS}

Segue os gráficos dos testes de normalidade para as estruturas analisadas. Todos os gráficos estão representados em milímetros (mm).

No gráfico 1 verifica-se a representação da estrutura SUPLG (Tendão Flexor Digital Superficial, mensuração de espessura).

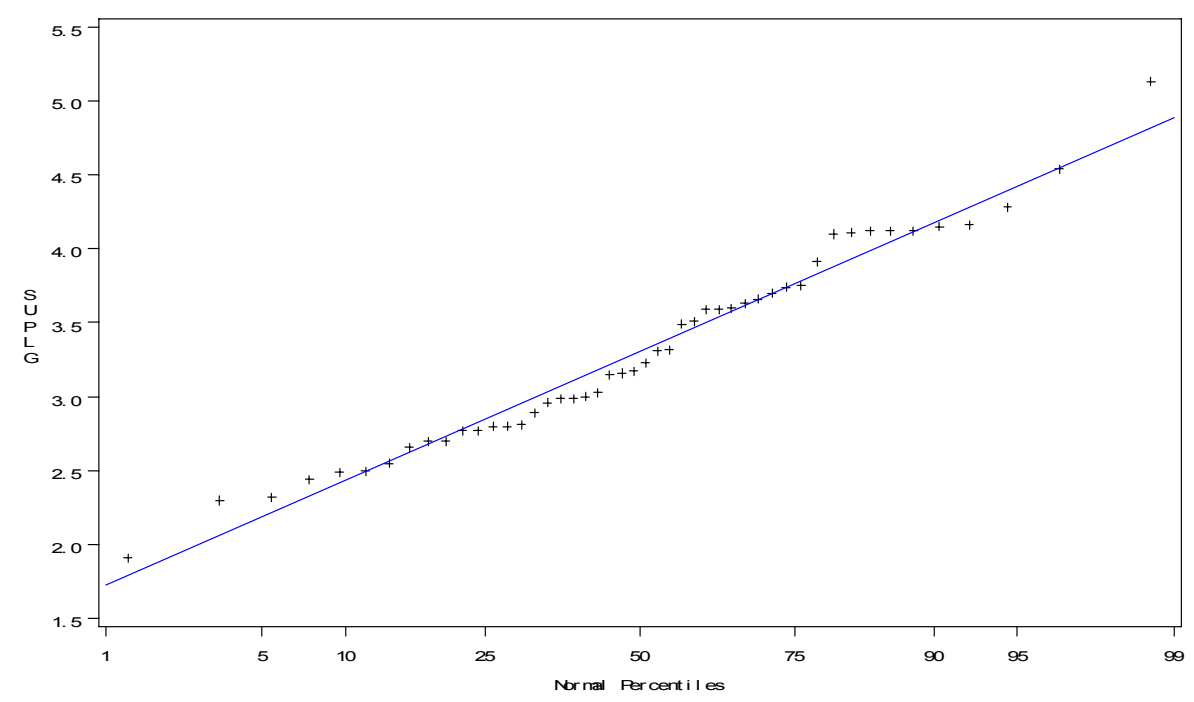

Gráfico 1 - Teste de normalidade para SUPLG

Já no gráfico 2 verifica-se a representação da estrutura SUPCP (Tendão Flexor Digital Superficial, mensuração de largura).

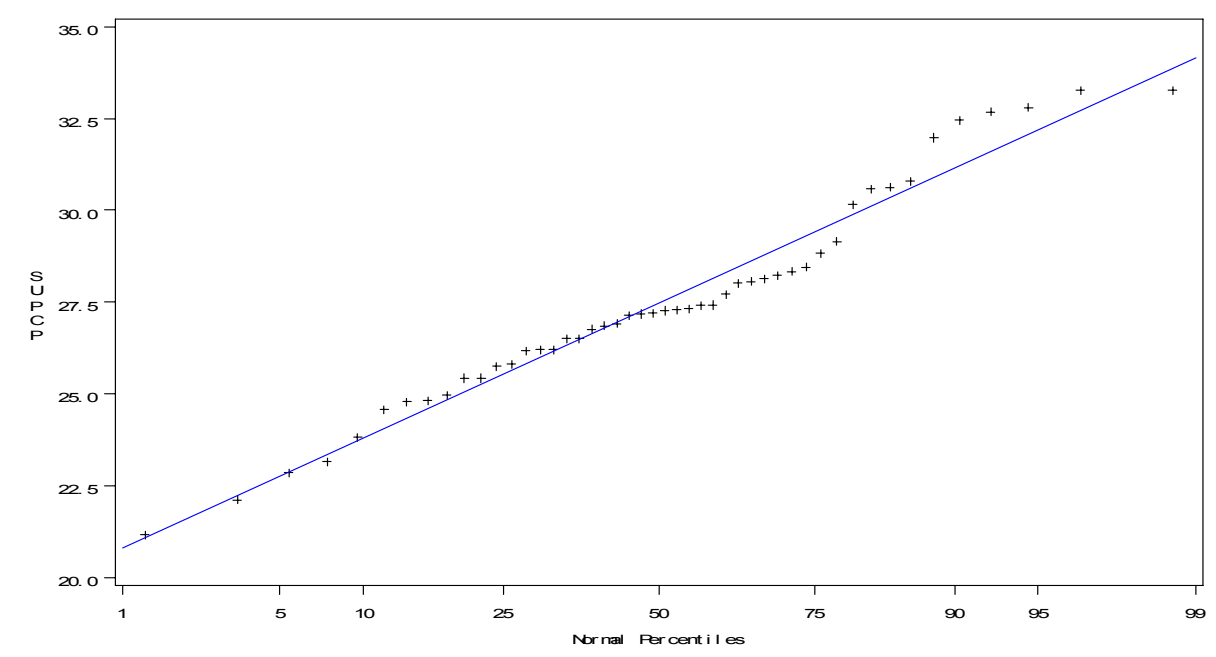

Gráfico 2 - Teste de normalidade para SUPCP 
No gráfico 3 pode-se visualizar a representação da estrutura PROFLG (Tendão Flexor Digital Profundo, mensuração de espessura).

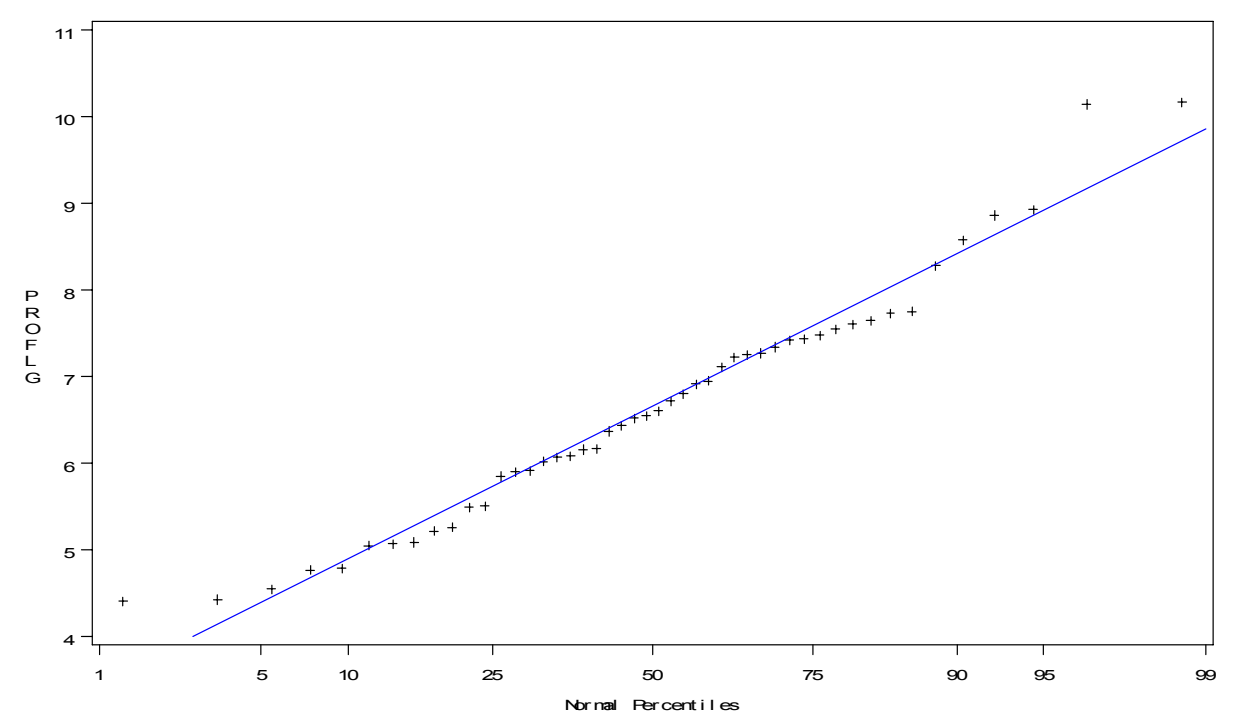

Gráfico 3 - Teste de normalidade para PROFLG

No gráfico 4 encontra-se a representação da estrutura PROFCP (Tendão Flexor Digital Profundo, mensuração de largura).

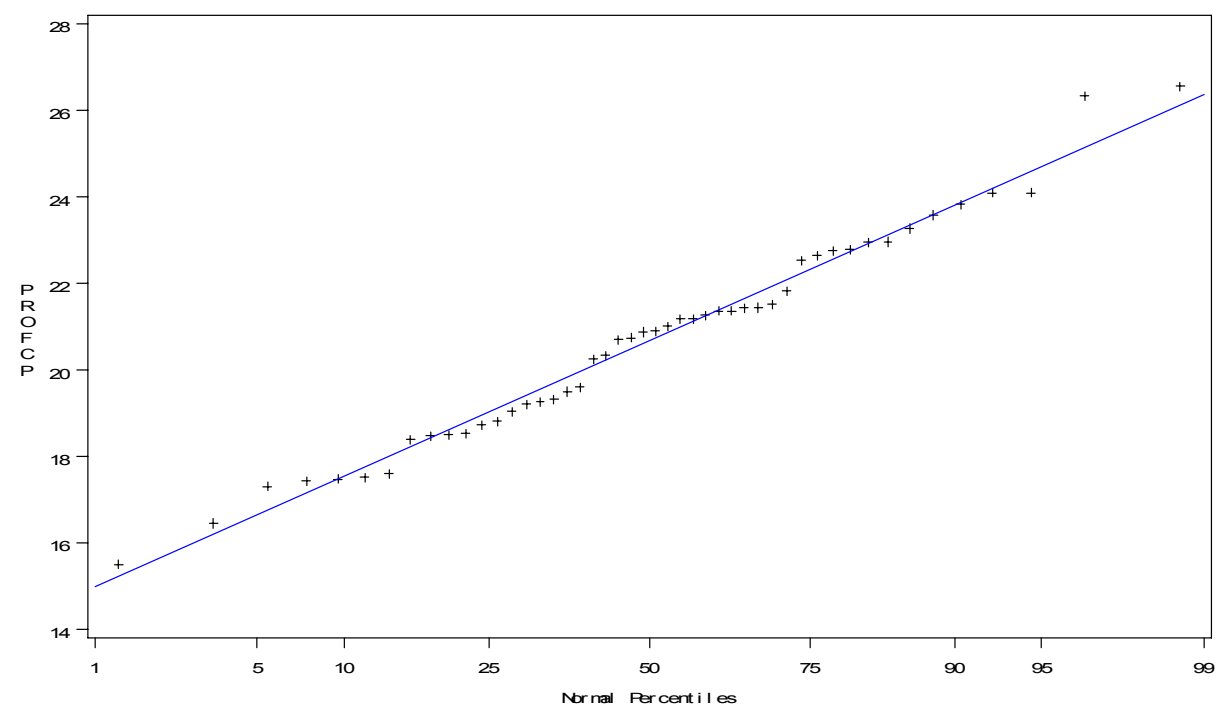

Gráfico 4 - Teste de normalidade para PROFCP

O gráfico 5 mostra a representação da estrutura CAPFR (Cápsula Articular, mensuração da porção plantar). 


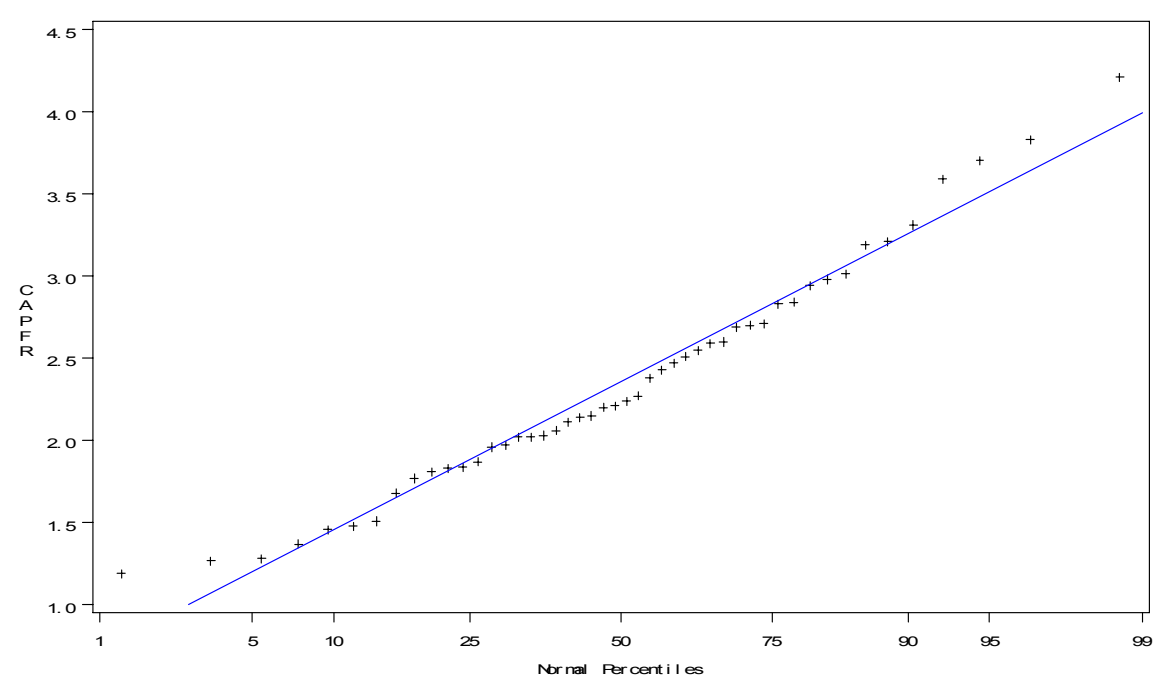

Gráfico 5 - Teste de normalidade para CAPFR

O gráfico 6 demonstra a representação da estrutura CAPTR (Cápsula Articular, mensuração da porção palmar).

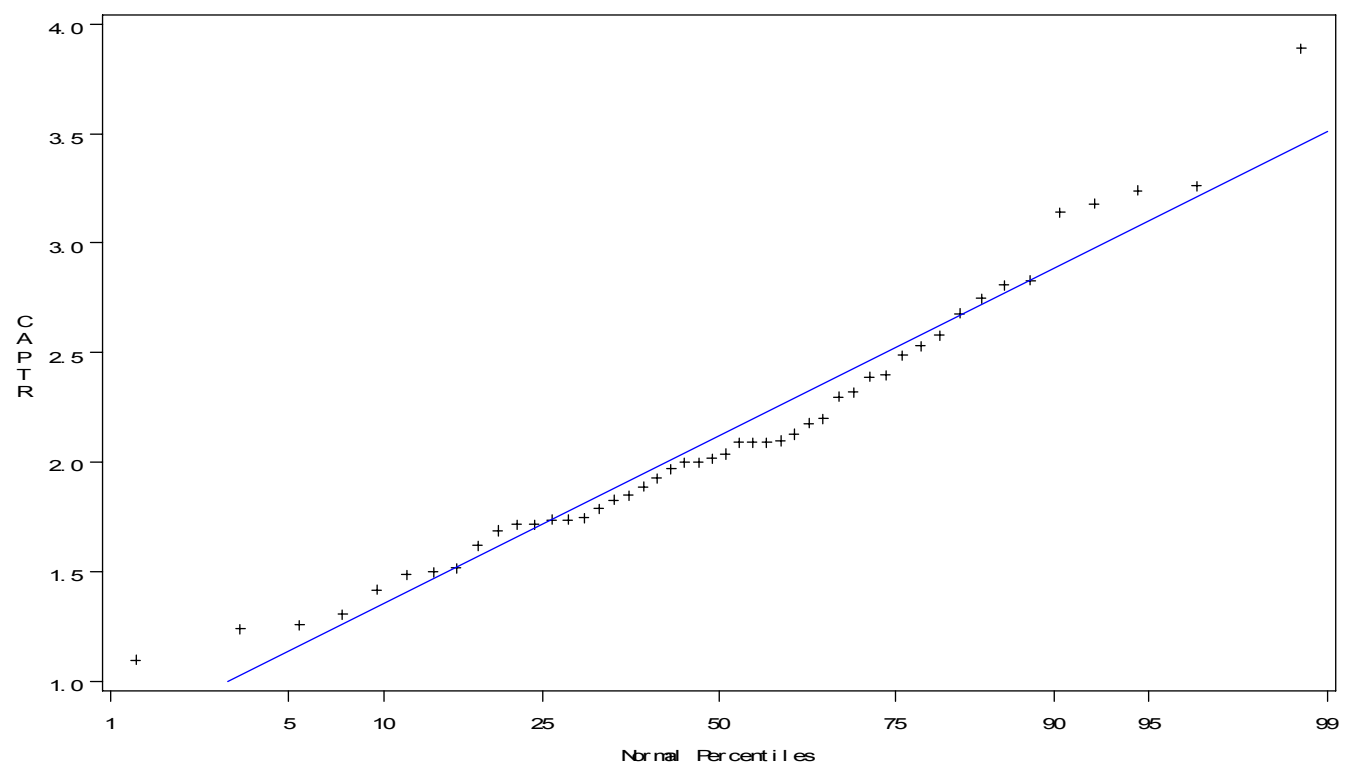

Gráfico 6 - Teste de normalidade para CAPTR

Já no gráfico 7 vê-se a representação da estrutura INTERLG (Ligamento Intersesamoideo, mensuração de espessura). 


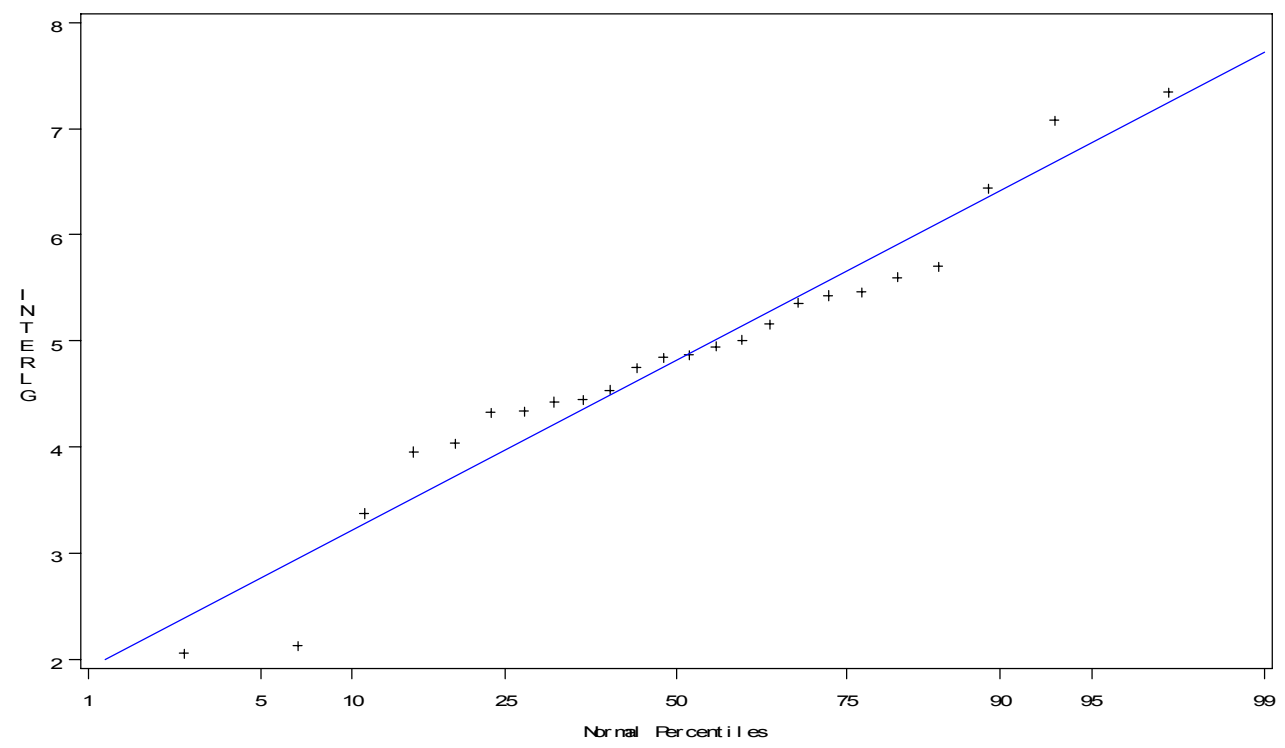

Gráfico 7 - Teste de normalidade para INTERLG

No gráfico 8 encontra-se a representação da estrutura INTERCP (Ligamento Intersesamoideo, mensuração de largura).

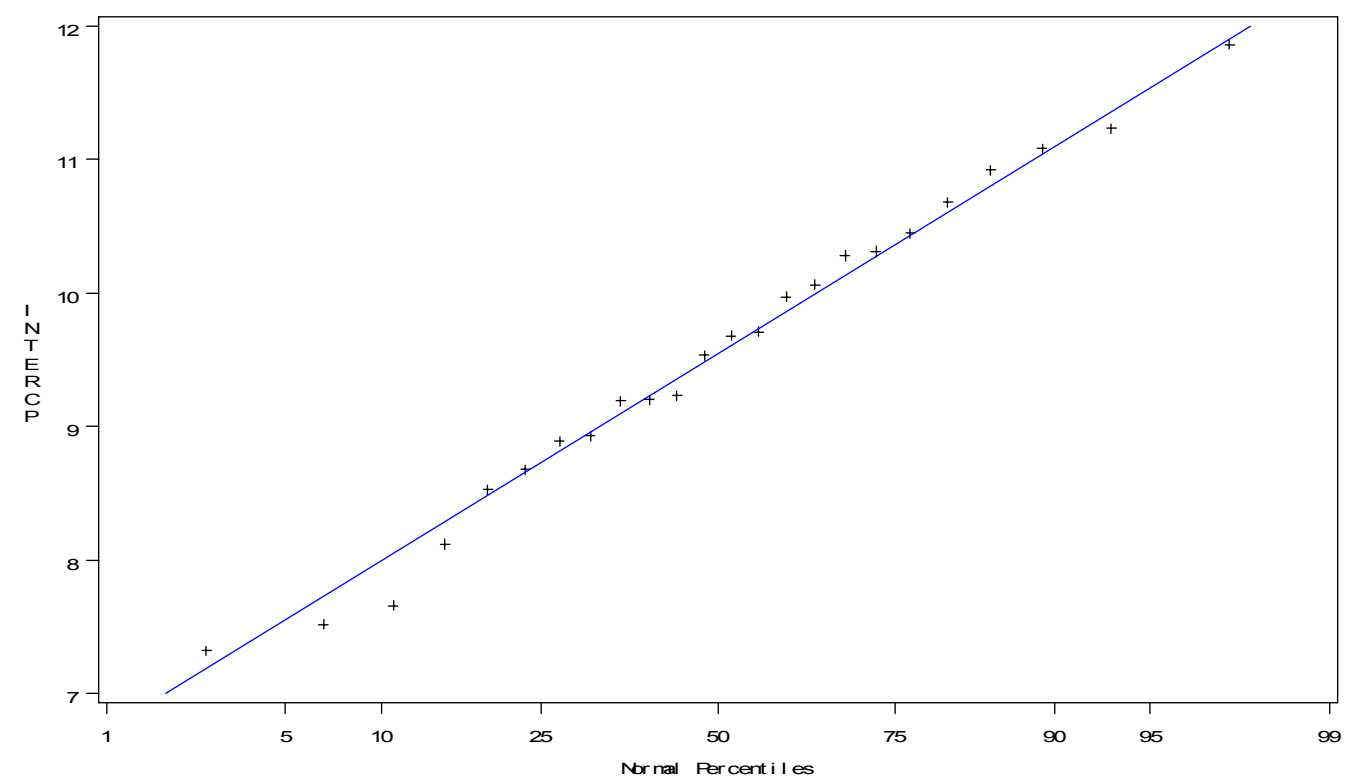

Gráfico 8 - Teste de normalidade para INTERCP

No gráfico 9 está a representação da estrutura EXTESQLG (Ligamento Extensor Esquerdo, mensuração de espessura). 


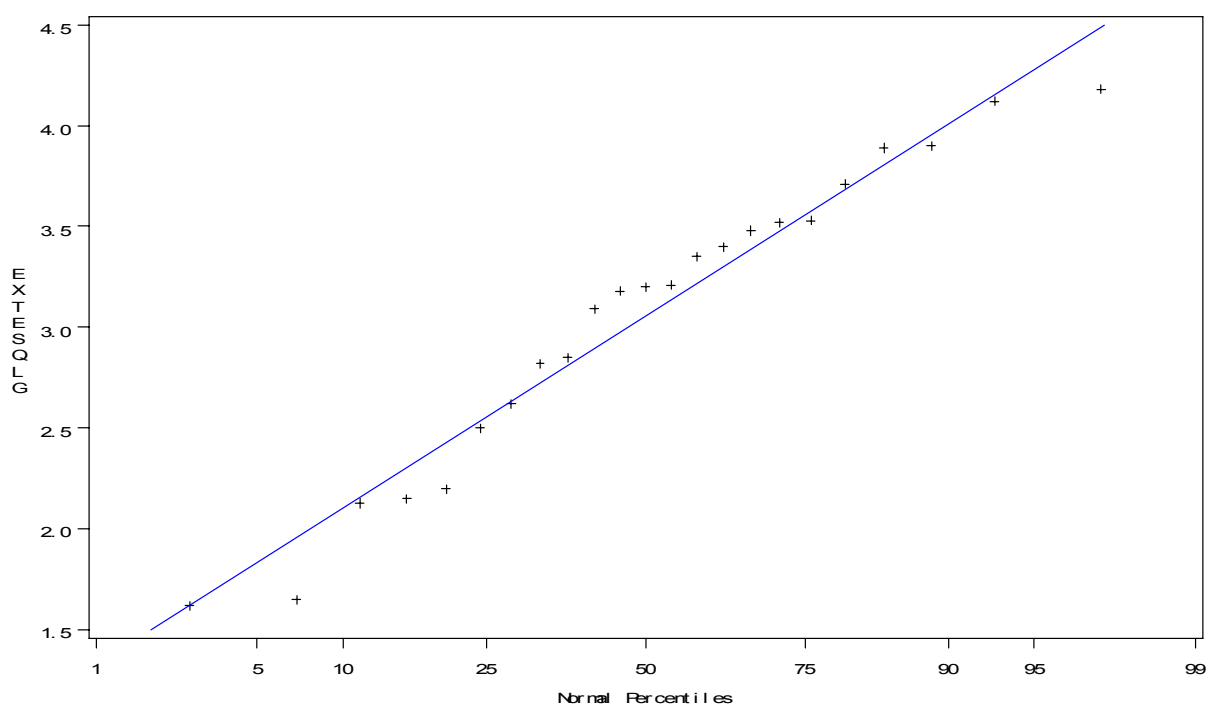

Gráfico 9 - Teste de normalidade para EXTESQLG

A representação da verificação de normalidade da estrutura EXTESQCP (Ligamento Extensor Esquerdo, mensuração de largura), está no gráfico 10.

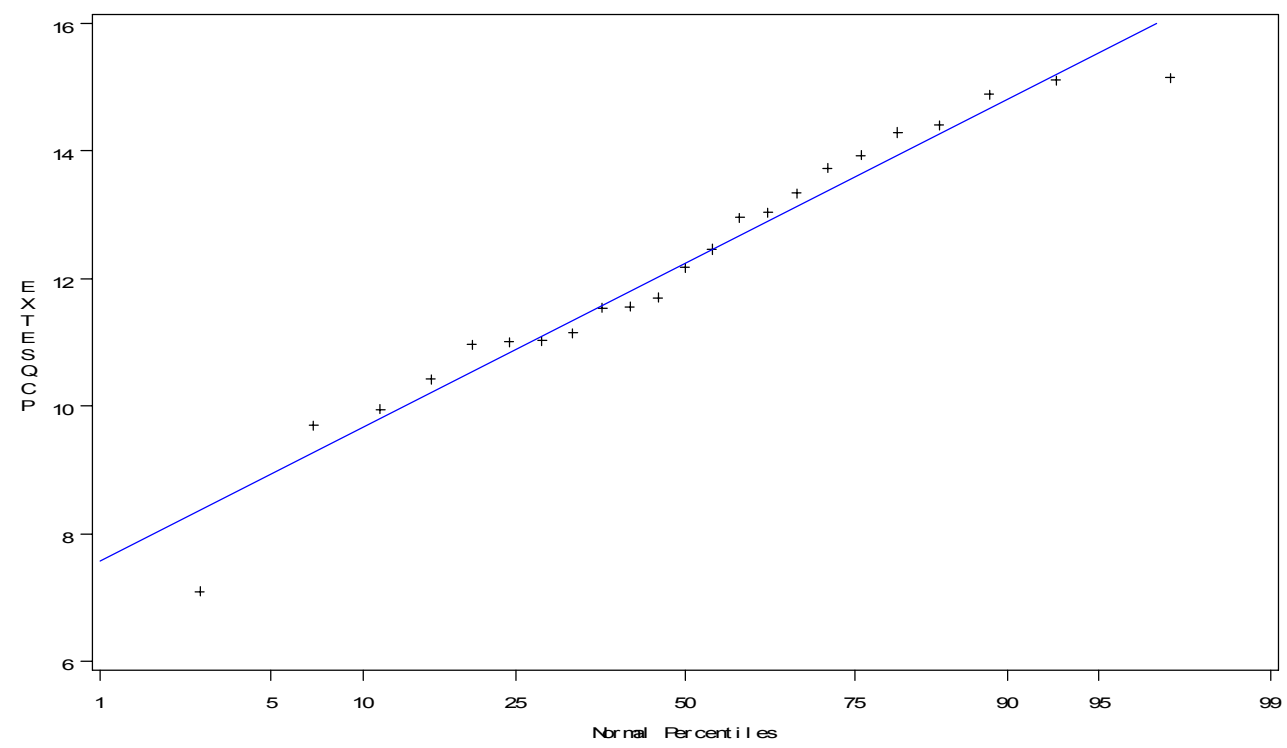

Gráfico10 - Teste de normalidade para EXTESQCP

No gráfico 11 verifica-se a representação da estrutura EXTDIRLG (Ligamento Extensor Direito, mensuração de espessura). 


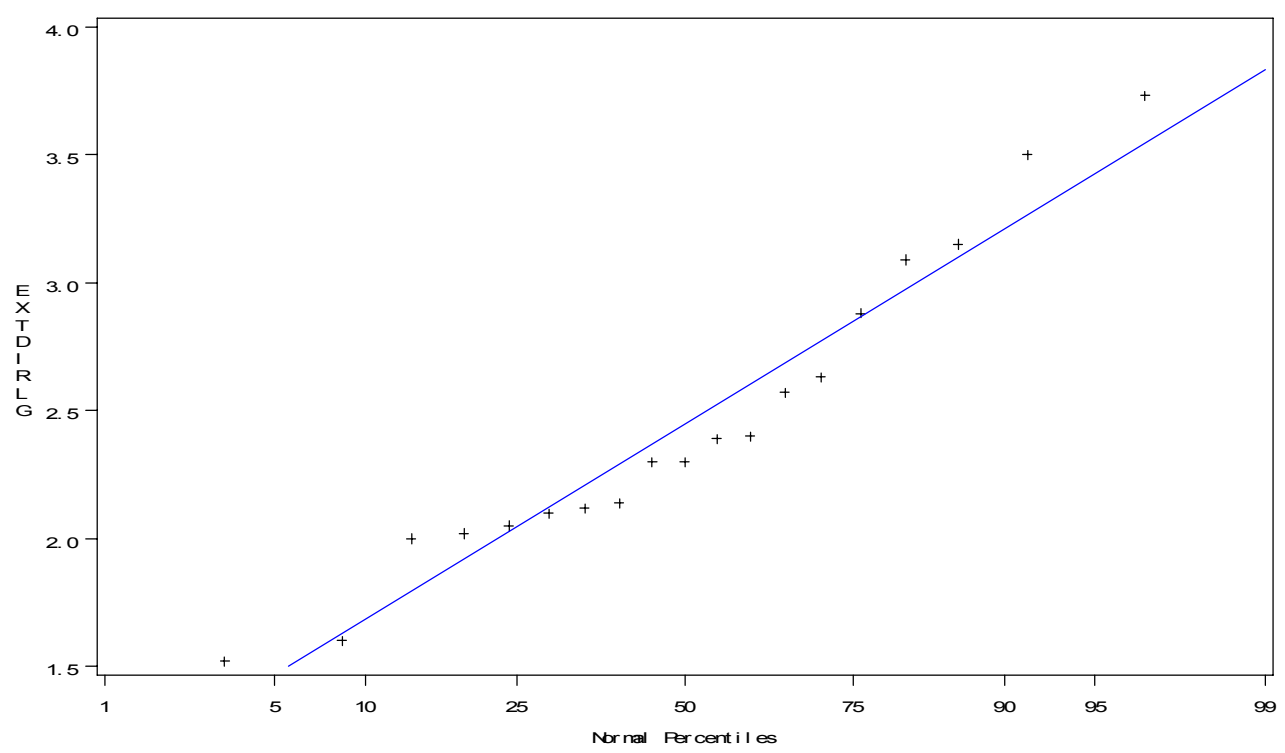

Gráfico 11 - Teste de normalidade para EXTDIRLG

No gráfico 12 encontra-se a representação da estrutura EXTDIRCP (Ligamento Extensor Direito, mensuração de largura).

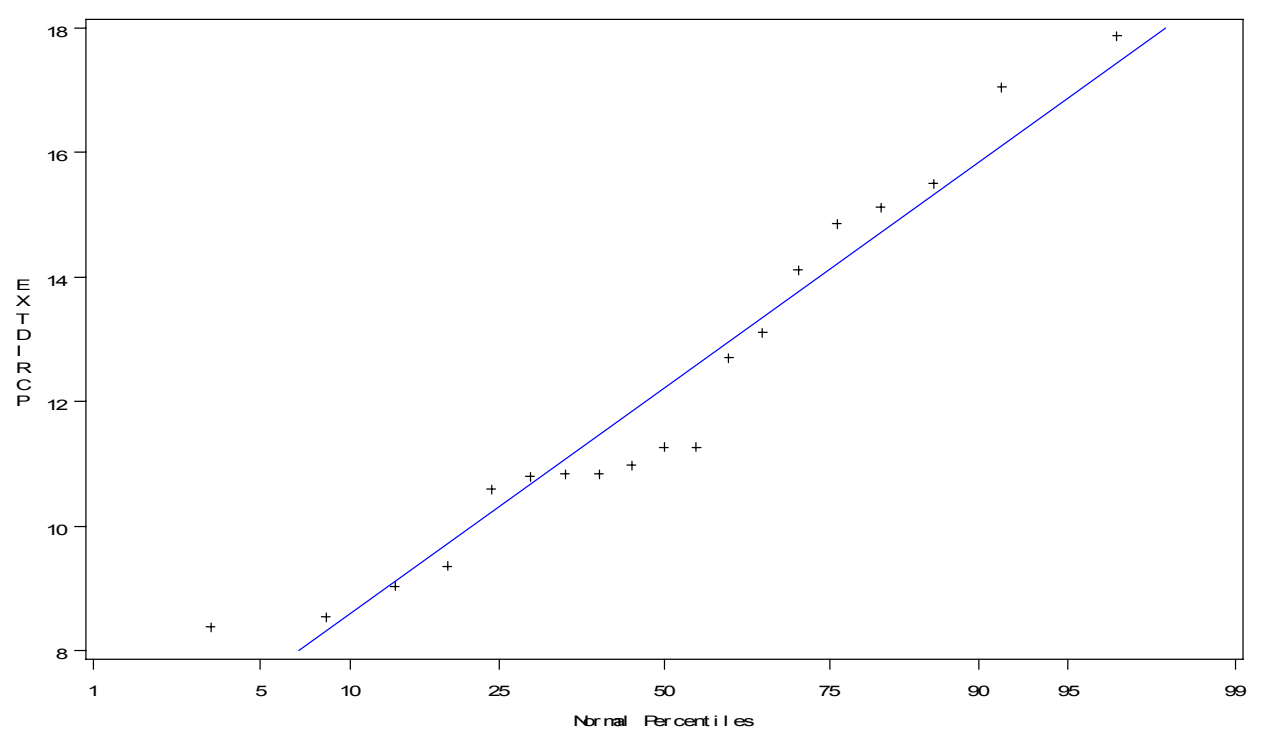

Gráfico 12 - Teste de normalidade para EXTDIRCP

No gráfico 13 localiza-se a representação da estrutura EXTLG (Ligamento Extensor, mensuração de espessura). 


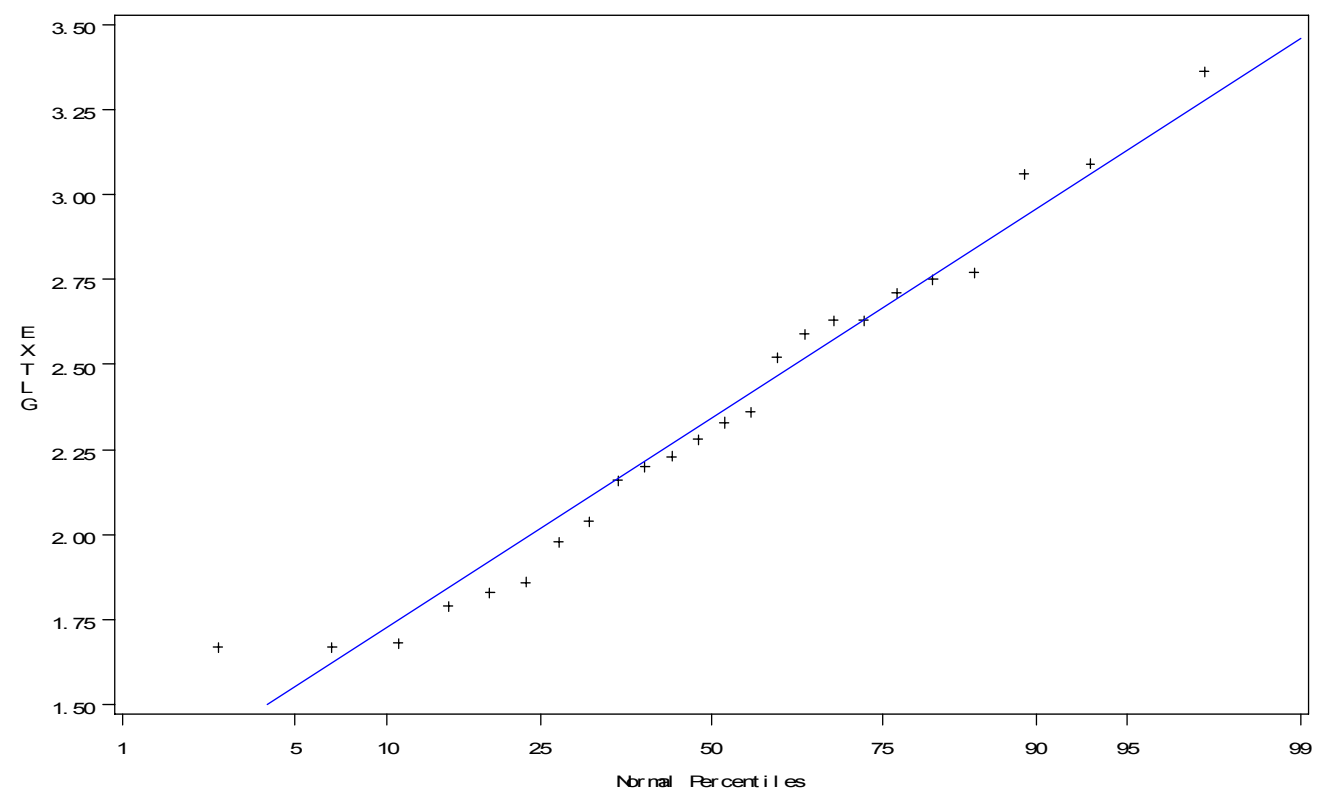

Gráfico13 - Teste de normalidade para EXTLG

No gráfico 14 encontramos a representação da estrutura EXTCP (Ligamento Extensor, mensuração de largura).

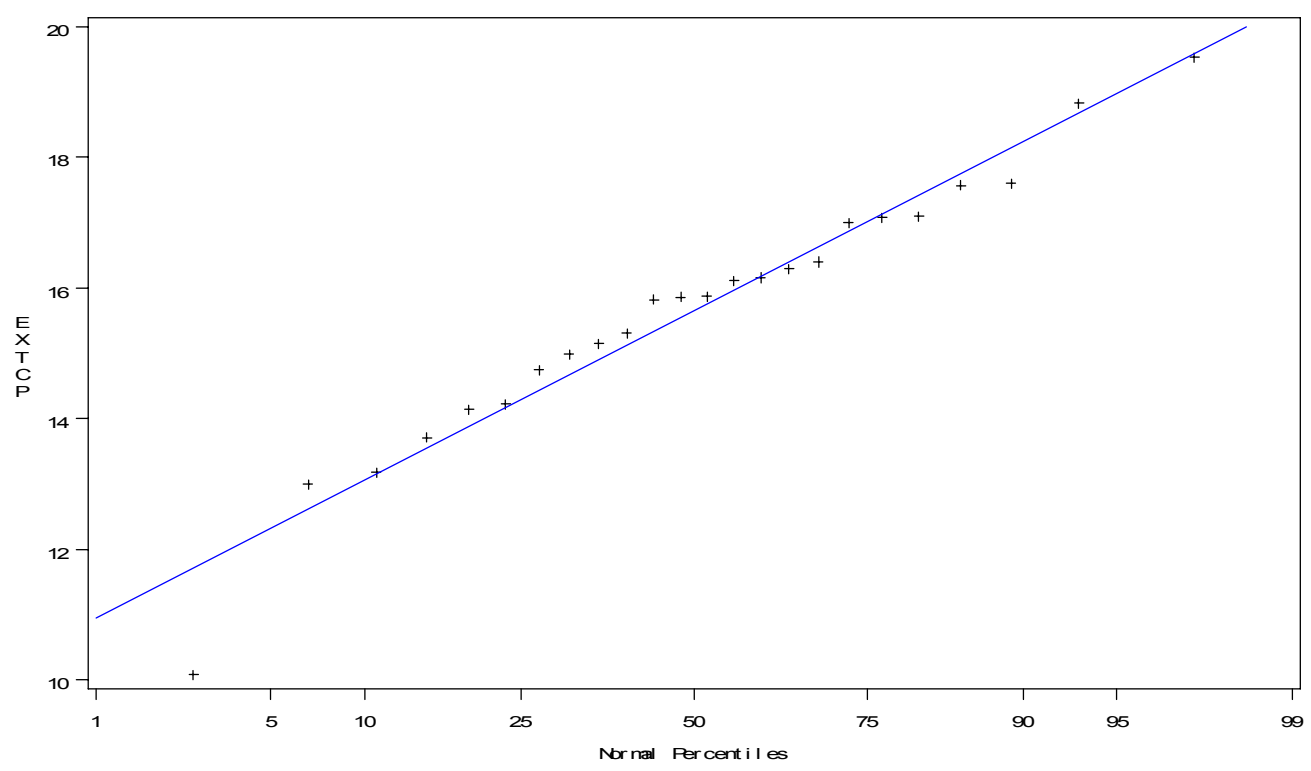

Gráfico 14 - Teste de normalidade para EXTCP

As estruturas estão aqui representadas pelas siglas na coluna de “variável”. 
Observa-se, pela tabela 1, que nenhuma das estruturas avaliadas, apresentou um desvio padrão considerado elevado, ou seja, acima de $40 \%$, para as características morfométricas avaliadas.

Tabela 1 - Descrição estatística geral para as estruturas avaliadas - São Paulo - 2005

\begin{tabular}{lrrrrrr}
\hline Variável & $\mathbf{N}$ & Média & DP & CV & MIN & MAX \\
\hline SUPLG & 48 & 3,307 & 0,680 & 20,573 & 1,910 & 5,130 \\
SUPCP & 48 & 27,477 & 2,865 & 10,428 & 21,170 & 33,260 \\
PROFLG & 48 & 6,654 & 1,374 & 20,645 & 4,410 & 10,160 \\
PROFCP & 48 & 20,674 & 2,441 & 11,808 & 15,510 & 26,540 \\
CAPFR & 48 & 2,354 & 0,703 & 29,851 & 1,190 & 4,210 \\
CAPTR & 48 & 2,121 & 0,597 & 28,137 & 1,100 & 3,890 \\
INTERLG & 24 & 4,819 & 1,248 & 25,899 & 2,060 & 7,340 \\
INTERCP & 24 & 9,543 & 1,211 & 12,691 & 7,320 & 11,860 \\
EXTESQLG & 23 & 3,057 & 0,744 & 24,328 & 1,620 & 4,180 \\
EXTESQCP & 23 & 12,241 & 2,006 & 16,384 & 7,100 & 15,150 \\
EXTDIRLG & 19 & 2,447 & 0,596 & 24,342 & 1,520 & 3,730 \\
EXTDIRCP & 19 & 12,221 & 2,831 & 23,164 & 8,390 & 17,870 \\
EXTLG & 24 & 2,341 & 0,480 & 20,481 & 1,670 & 3,360 \\
EXTCP & 24 & 15,653 & 2,021 & 12,913 & 10,080 & 19,530 \\
\hline
\end{tabular}


No gráfico 15 é possível verificar que nenhuma das estruturas avaliadas apresentou altos coeficientes de variação.

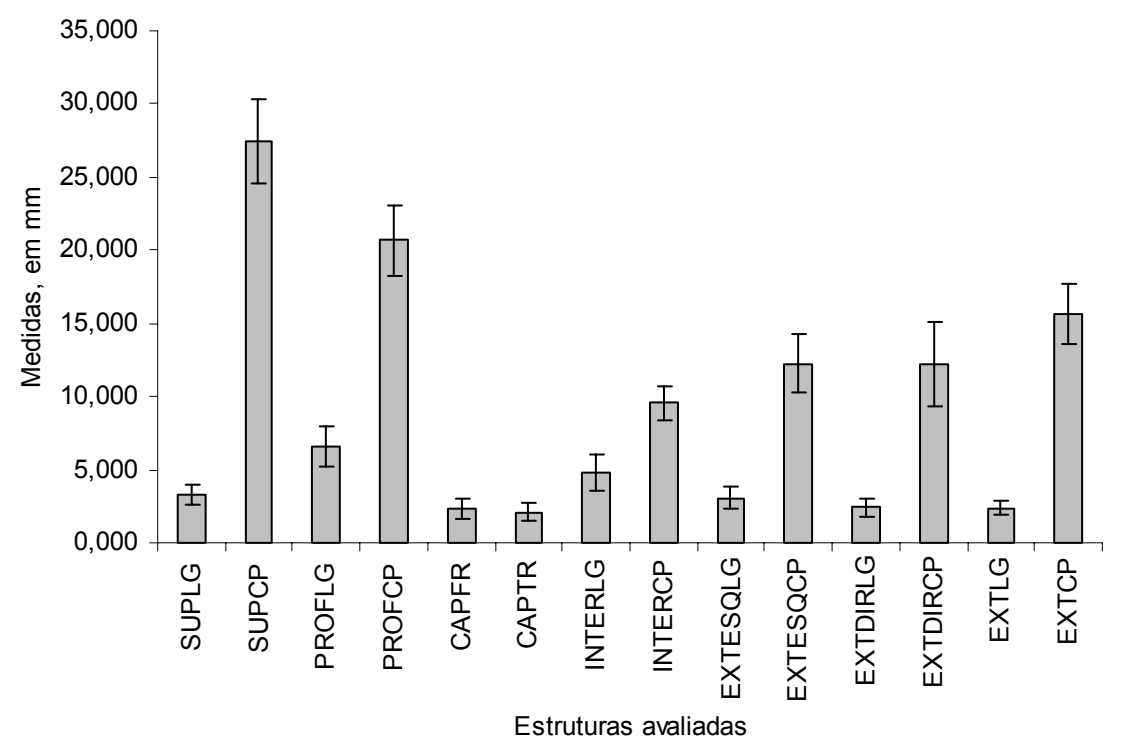

Gráfico 15 - Estimativas de média e os respectivos desvios padrão observados, para as estruturas avaliadas.

Observa-se, pela tabela 2 e pelo gráfico 16, que todas as estruturas avaliadas, apresentaram um intervalo de confiança, bastante baixo e que suas médias estão todas muito próximas de seus limites superiores e inferiores.

Todas as estruturas avaliadas podem variar dentro da população dentre os valores encontrados nas colunas de limite inferior e superior. 
Tabela 2 - Intervalo de Confiança de $95 \%$ de probabilidade para as estruturas analisadas - São Paulo - 2005

\begin{tabular}{lccc}
\hline Variável & Limite Inferior & Média & Limite Superior \\
\hline SUPLG & 3,109 & 3,307 & 3,504 \\
SUPCP & 26,645 & 27,477 & 28,309 \\
PROFLG & 6,255 & 6,654 & 7,052 \\
PROFCP & 19,965 & 20,674 & 21,383 \\
CAPFR & 2,150 & 2,354 & 2,558 \\
CAPTR & 1,948 & 2,121 & 2,294 \\
INTERLG & 4,292 & 4,819 & 5,346 \\
INTERCP & 9,032 & 9,543 & 10,054 \\
EXTESQLG & 2,735 & 3,057 & 3,378 \\
EXTESQCP & 11,374 & 12,241 & 13,108 \\
EXTDIRLG & 2,160 & 2,447 & 2,734 \\
EXTDIRCP & 10,857 & 12,221 & 13,585 \\
EXTLG & 2,139 & 2,341 & 2,544 \\
EXTCP & 14,800 & 15,653 & 16,507 \\
\hline
\end{tabular}

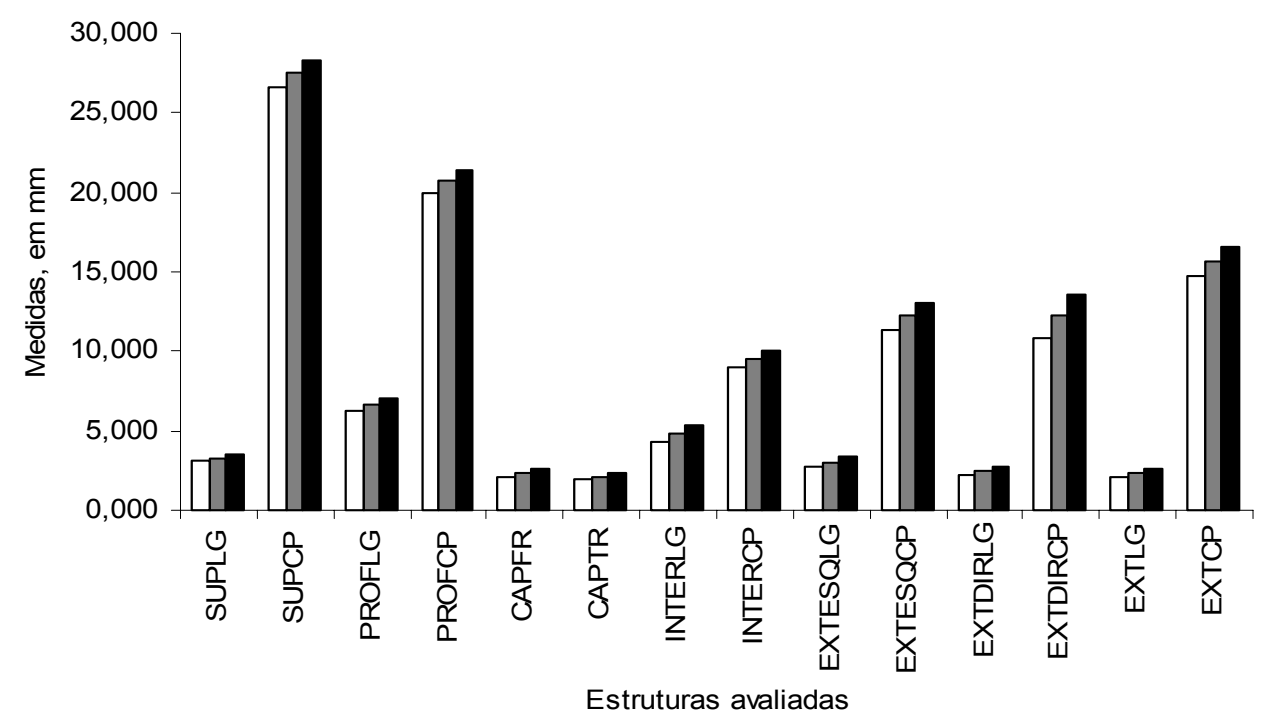

$\square$ Limite Inferior $\square$ Média $\square$ Limite Superior

Gráfico 16 - Intervalos de confiança para as estruturas avaliadas 
Observa-se, pela tabela 3, que as estruturas SUPLG, SUPCP, PROFCP e CAPFR apresentaram resultados não-significativos $(P<0,05)$ para as Fontes de Variação avaliadas (representados na tabela pelo símbolo ns). Entretanto, para PROFLG foi verificado efeito significativo $(P>0,01)$ para a Fonte de Variação Porção (representado na tabela pelo símbolo **) e para CAPTR, foi encontrado e efeito significativo $(P>0,05)$ para a Fonte de Variação Lado de mensuração (representado na tabela pelo símbolo *).

Tabela 3 - Resumo das análises de variâncias para as estruturas avaliadas em relação às porções e aos lados - São Paulo - 2005

\begin{tabular}{|c|c|c|c|c|c|c|c|c|c|c|c|c|c|}
\hline \multirow[t]{2}{*}{ FV } & \multirow[t]{2}{*}{ GL } & \multicolumn{12}{|c|}{ Quadrados Médios } \\
\hline & & SUPLG & & SUPCP & & PROFLG & & PROFCP & & CAPFR & & CAPTR & \\
\hline Porção (P) & 1 & 1,006 & ns & 12,302 & ns & 28,353 & $* *$ & 20,346 & ns & 1,945 & ns & 0,498 & ns \\
\hline Lado (L) & 1 & 0,002 & ns & 0,183 & ns & 4,114 & ns & 6,305 & ns & 0,016 & ns & 1,875 & * \\
\hline Int. P x L & 1 & 0,006 & ns & 2,078 & ns & 0,000 & ns & 0,269 & ns & 0,104 & ns & 0,485 & ns \\
\hline Resíduo & 44 & 0,471 & & 8,455 & & 1,273 & & 5,742 & & 0,482 & & 0,313 & \\
\hline
\end{tabular}

$\mathrm{Na}$ tabela 4 visualiza-se as médias de quadrados mínimos para as estruturas avaliadas em relação às porções e aos lados, onde é possível notar que a estrutura PROFLG apresentou uma diferença somente em relação à porção analisada (representado na tabela pela letra b na coluna da estrutura), e a estrutura CAPTR apresentou diferença apenas em relação ao lado analisado (representado pela letra b na coluna da estrutura).

Tabela 4 - Médias de quadrados mínimos para as estruturas avaliadas em relação às porções e aos lados - São Paulo - 2005

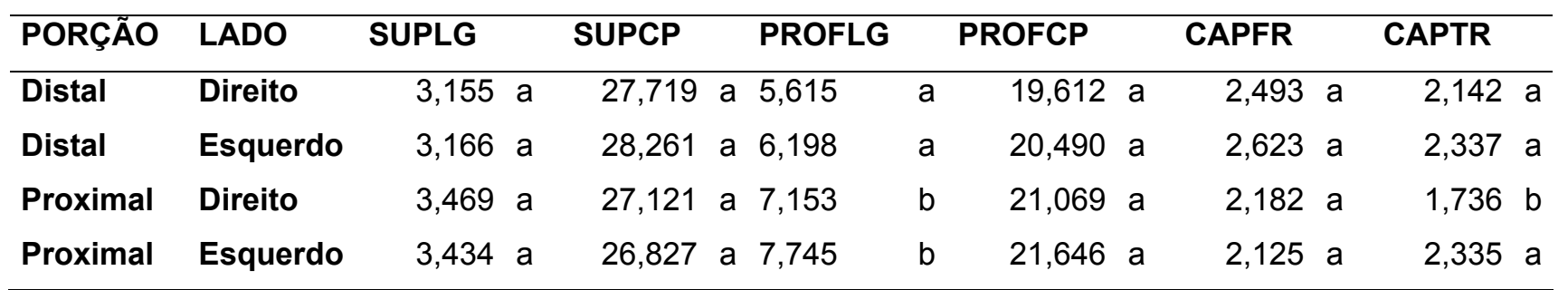


Na tabela 5 verificamos as análises de variância, feitas para o Ligamento Intersesamoideo em relação às porções proximais, que não apresentou resultado significativo para o fator de variância analisado.

Tabela 5 - Resumo das análises de variâncias para a estrutura Intersessamoideo em relação às porções proximais - São Paulo - 2005

\begin{tabular}{llrc}
\hline FV & GL & \multicolumn{2}{c}{ Quadrados Médios } \\
\hline & & INTERLG & \multicolumn{1}{c}{ INTERCP } \\
\cline { 3 - 4 } Lado (L) & 1 & $0,001 \mathrm{~ns}$ & $0,115 \mathrm{~ns}$ \\
Resíduo & 22 & 1,629 & 1,528 \\
\hline
\end{tabular}

Já na tabela 6 é possível verificar as análises de variâncias para o ligamento extensor esquerdo em relação às porções proximais que não apresentou resultado significativo para o fator de variância analisado.

Tabela 6 - Resumo das análises de variâncias para o ligamento extensor esquerdo em relação às porções proximais - São Paulo - 2005

\begin{tabular}{llcc}
\hline FV & GL & \multicolumn{2}{c}{ Quadrados Médios } \\
\hline & & EXTESQLG & EXTESQCP \\
\cline { 3 - 4 } Lado (L) & 1 & $0,123 \mathrm{~ns}$ & $9,607 \mathrm{~ns}$ \\
Resíduo & 21 & 0,573 & 3,756 \\
\hline
\end{tabular}

Na tabela 7 verifica-se o resumo das análises de variâncias para o ligamento extensor direito em relação às porções proximais que não apresentou resultado significativo para o fator de variância analisado. 
Tabela 7 - Resumo das análises de variâncias para o ligamento extensor direito em relação às porções proximais - São Paulo - 2005

\begin{tabular}{llcl}
\hline FV & GL & \multicolumn{2}{c}{ Quadrados Médios } \\
\hline & & EXTDIRLG & EXTDIRCP \\
\cline { 2 - 3 } Lado (L) & 1 & $0,283 \mathrm{~ns}$ & $0,039 \mathrm{~ns}$ \\
Resíduo & 17 & 0,359 & 8,483
\end{tabular}

Observa-se, pela tabela 8, que as estruturas INTERLG, INTERCP, EXTESQLG, EXTESQCP, EXTDIRLG, EXTDIRCP, apresentaram resultados não significativos para a Fonte de Variação avaliada.

Tabela 8 - Médias de quadrados mínimos para as estruturas avaliadas nas porções proximais em relação aos lados - São Paulo - 2005

\begin{tabular}{lrrrrrr}
\hline LADO & INTERLG & INTERCP & EXTESQLG & EXTESQCP & EXTDIRLG & EXTDIRCP \\
\hline Direito & $4,825 \mathrm{a}$ & $9,479 \mathrm{a}$ & $3,121 \mathrm{a}$ & $12,808 \mathrm{a}$ & $2,331 \mathrm{a}$ & $12,264 \mathrm{a}$ \\
Esquerdo & $4,813 \mathrm{a}$ & $9,618 \mathrm{a}$ & $2,973 \mathrm{a}$ & $11,504 \mathrm{a}$ & $2,576 \mathrm{a}$ & $12,173 \mathrm{a}$ \\
\hline
\end{tabular}

O resumo das análises de variâncias para as dimensões da estrutura ligamento extensor em relação às porções distais se encontram na tabela 9.

Tabela 9 - Resumo das análises de variâncias para as estruturas avaliadas em relação às porções distais - São Paulo - 2005

\begin{tabular}{llll} 
FV & GL & \multicolumn{2}{c}{ Quadrados Médios } \\
\hline & & EXTLG & EXTCP \\
\cline { 3 - 4 } Lado (L) & 1 & $0,033 \mathrm{~ns}$ & $0,878 \mathrm{~ns}$ \\
Resíduo & 22 & 0,239 & 4,231 \\
\hline
\end{tabular}

Observa-se, pela tabela 10, que as estruturas: EXTLG, EXTCP, não apresentaram diferenças estatísticas para as Fontes de Variação avaliadas. 
Tabela 10 - Médias de quadrados mínimos para as estruturas avaliadas nas porções distais em relação aos lados - São Paulo - 2005

\begin{tabular}{lcc}
\hline LADO & EXTLG & EXTCP \\
\hline Direito & $2,375 a$ & $15,829 a$ \\
Esquerdo & $2,301 a$ & $15,445 a$ \\
\hline
\end{tabular}

Segundo a tabela 11 observamos estimativas de correlações entre estruturas avaliadas em relação às porções distais.

As estimativas de correlações foram baixas para a grande maioria das estruturas avaliadas, com valores que oscilaram de 0,038 (entre EXTLG e PTOFCP) a 0,488 (entre CAPFR e PROFLG). Entre as estruturas CAPTR e PROFLG, bem como CAPFR e PROFCP, foram verificadas correlações medianas de 0,508 e 0,632, respectivamente.

Correlações altas, com valores de 0,758 a 0,871 , foram verificadas entre as estruturas CAPFR e SUPCP e PROFCP E SUPCP, respectivamente.

Tabela 11 - Estimativas de correlações entre as estruturas avaliadas em relação às porções distais - São Paulo - 2005

\begin{tabular}{lllllllll}
\hline & SUPLG & SUPCP & PROFLG & PROFCP & CAPFR & CAPTR & EXTLG & EXTCP \\
\hline SUPLG & 1,000 & 0,531 & 0,295 & 0,325 & 0,561 & 0,175 & 0,109 & 0,339 \\
SUPCP & 0,531 & 1,000 & 0,623 & 0,871 & 0,758 & 0,413 & 0,114 & 0,390 \\
PROFLG & 0,295 & 0,623 & 1,000 & 0,809 & 0,488 & 0,508 & 0,069 & 0,078 \\
PROFCP & 0,325 & 0,871 & 0,809 & 1,000 & 0,632 & 0,337 & 0,038 & 0,120 \\
CAPFR & 0,561 & 0,758 & 0,488 & 0,632 & 1,000 & 0,445 & 0,059 & 0,331 \\
CAPTR & 0,175 & 0,413 & 0,508 & 0,337 & 0,445 & 1,000 & 0,210 & 0,156 \\
EXTLG & 0,109 & 0,114 & 0,069 & 0,038 & 0,059 & 0,210 & 1,000 & 0,241 \\
EXTCP & 0,339 & 0,390 & 0,078 & 0,120 & 0,331 & 0,156 & 0,241 & 1,000 \\
\hline
\end{tabular}

Pela tabela 12 observamos estimativas de correlações entre as estruturas avaliadas nas porções proximais. 
As estimativas de correlações foram baixas para a grande maioria das estruturas avaliadas, com valores que oscilaram de -0,330 (entre EXTESQCP e CAPTR) a 0,490 (entre PROFLG e SUPCP). Entre as estruturas INTERCP e PROFLG, bem como INTERCP e SUPCP, foram verificadas correlações medianas de 0,555 e 0,681 respectivamente.

Para as estruturas PROFCP e SUPCP, foi verificada estimativa de correlação moderadamente alta com valor de 0,736. 
Tabela 12: Estimativas de correlações entre as estruturas avaliadas nas porções proximais - São Paulo - 2005

\begin{tabular}{|c|c|c|c|c|c|c|c|c|c|c|c|c|}
\hline & SUPLG & SUPCP & PROFLG & PROFCP & CAPFR & CAPTR & INTERLG & INTERCP & EXTESQLG & EXTESQCP & EXTDIRLG & EXTDIRCP \\
\hline SUPLG & 1,000 & 0,429 & 0,654 & 0,474 & 0,327 & $-0,004$ & 0,374 & 0,639 & 0,323 & 0,055 & 0,164 & 0,456 \\
\hline SUPCP & 0,429 & 1,000 & 0,490 & 0,736 & 0,250 & 0,023 & 0,180 & 0,681 & $-0,141$ & $-0,012$ & 0,378 & 0,461 \\
\hline PROFLG & 0,654 & 0,490 & 1,000 & 0,478 & 0,141 & 0,110 & 0,212 & 0,555 & 0,226 & $-0,287$ & 0,302 & 0,313 \\
\hline PROFCP & 0,474 & 0,736 & 0,478 & 1,000 & 0,245 & 0,304 & 0,324 & 0,601 & 0,005 & $-0,055$ & 0,115 & 0,387 \\
\hline CAPFR & 0,327 & 0,250 & 0,141 & 0,245 & 1,000 & 0,360 & 0,235 & 0,418 & 0,248 & 0,223 & $-0,005$ & 0,290 \\
\hline CAPTR & $-0,004$ & 0,023 & 0,110 & 0,304 & 0,360 & 1,000 & 0,040 & 0,149 & 0,038 & $-0,330$ & 0,159 & 0,123 \\
\hline INTERLG & 0,374 & 0,180 & 0,212 & 0,324 & 0,235 & 0,040 & 1,000 & 0,127 & 0,196 & 0,187 & $-0,065$ & $-0,039$ \\
\hline INTERCP & 0,639 & 0,681 & 0,555 & 0,601 & 0,418 & 0,149 & 0,127 & 1,000 & $-0,007$ & 0,082 & 0,206 & 0,456 \\
\hline EXTESQLG & 0,323 & $-0,141$ & 0,226 & 0,005 & 0,248 & 0,038 & 0,196 & $-0,007$ & 1,000 & 0,204 & $-0,229$ & 0,068 \\
\hline EXTESQCP & 0,055 & $-0,012$ & $-0,287$ & $-0,055$ & 0,223 & $-0,330$ & 0,187 & 0,082 & 0,204 & 1,000 & $-0,138$ & $-0,151$ \\
\hline EXTDIRLG & 0,164 & 0,378 & 0,302 & 0,115 & $-0,005$ & 0,159 & $-0,065$ & 0,206 & $-0,229$ & $-0,138$ & 1,000 & 0,556 \\
\hline EXTDIRCP & 0,456 & 0,461 & 0,313 & 0,387 & 0,290 & 0,123 & $-0,039$ & 0,456 & 0,068 & $-0,151$ & 0,556 & 1,000 \\
\hline
\end{tabular}




\section{DISCUSSÃo}

Apesar da facilidade de obtenção de uma boa quantidade de peças anatômicas, uma vez que as mesmas tiveram como procedência o abatedouro e frigorífico POMAR, deparou-se com a mesma problemática que Macoris e Bertone (2001), ou seja, a dificuldade de obter peças da articulação metacarpofalangeana hígida.

O critério de descarte de peças se baseou no exame visual das mesmas e qualquer alteração encontrada (aumento de volume, miíase, etc.) foi suficiente para o descarte da peça, o que acarretou a diferença na quantidade de peças em relação aos lados (direito e esquerdo).

$\mathrm{O}$ armazenamento a baixas temperaturas (aproximadamente $3^{\circ} \mathrm{C}$ ), feito logo após a secção, foi necessário para que as mesmas se mantivessem morfofisiologicamente intactas até o momento de congelamento das mesmas e se mostrou eficiente para que o experimento fosse efetuado.

A posição que as peças foram colocadas, no momento de congelá-las, procurou buscar a posição do animal em estação, para que as mesmas representassem o animal vivo no momento de coletar os dados.

Durante o processo de dissecação foi possível observar e identificar as estruturas que compõem a articulação metacarpofalangeana, como colocado por Bradley (1920); Dyce, Sack e Wensing (1997, 2004); Getty (1986) König e Liebich (2002)'; Nickel et al. (1986); Ross e Dyson (2003) e Schaller (1999).

A verificação da presença do ligamento intersesamoideo só foi possível após a retirada dos tendões flexores digitais, superficial e profundo, e da 
bainha que os envolve, sendo está firmemente aderida o que dificultou bastante sua retirada.

Os ligamentos extensores ao passarem pela articulação metacarpofalangeana se unem, formando um só, como colocado por Dyce, Sack e Wensing (1997, 2004); Getty (1986); Nickel et al. (1986) e Schaller (1999). E ainda concordando com os autores que também colocam que para visualizar os ligamentos palmares, sesamoideos curtos e ligamentos cruzados é necessário uma nova abordagem na dissecação, ou seja, é necessário efetuar a retirada dos ossos sesamóides.

A verificação da presença do côndilo e da quilha axial na porção distal do Terceiro Osso Metacarpiano e a comprovação de que essas estruturas se articulam com a porção proximal da Falange Proximal e com os Ossos Sesamóides Proximais, nos levaram a concordar com Dyce, Sack e Wensing (1997, 2004) e com Ross e Dyson (2003), mas não foi possível concordar com estes mesmos autores no ponto em que eles colocam que o único elemento funcional do terceiro osso metacarpiano é sua porção distal e que ainda, sua porção proximal serve apenas para apoiar os Ossos do Carpo, uma vez que confrontando esses dados com os dados apresentados por Bogert (1989) e Eziliano (2001), visualizou-se que existe para a porção proximal do Terceiro Metacarpiano a função de, dentro de um conjunto, dissipar forças exercidas, produzidas e sofridas pelos membros torácicos dos animais.

Observou e identificou-se também os seguintes ligamentos: Ligamentos Colaterais e constatou-se que eles se apresentam em número de dois por articulação; ligamento metacarpointersesamóideo, onde verificou-se sua extensão do Terceiro Osso Metacarpiano aos Ossos Sesamóides Proximais; 
Ligamento Sesamóide Reto e suas faces de inserção, como colocado por Dyce, Sack, Wensing (1997, 2004); Getty (1986); Nickel et al. (1986); Ross, Dyson (2003) e Schaller (1999).

Segundo Getty (1986) e Dyce, Sack e Wensing (1997, 2004), o "machinho" está na exata região do Osso Sesamóide Proximal Lateral, que é facilmente palpável e sugestiva de se estar distal a articulação metacarpofalangeana, por esse motivo, utilizamos a porção distal dessa estrutura como marco para a primeira marcação e pelo objetivo de fazer as mensurações logo após a junção óssea, calculou-se aproximadamente uma medida que se atende à expectativa de conseguir separar a articulação propriamente dita. Baseou-se na medida que melhor se apresentou nos pilotos efetuados.

Baseado nos dados colhidos durante a fase piloto do estudo, percebeuse que utilizando o ponto mediano exato das estruturas criaríamos um padrão na forma e lugar de mensuração para as medidas de espessura das estruturas mensuradas e que para medir a largura das estruturas percebemos que se posicionássemos o paquímetro nas porções mais afastadas da estrutura teríamos um outro padrão, levando em consideração nos dois casos às particularidades de cada indivíduo.

Depois de efetuada as análises estatísticas, verificou-se que todas as análises de variação de normalidade foram efetuadas para proporcionar a certeza de que os dados eram suficientes e confiáveis para analisar outras variáveis. Todas as estruturas mensuradas e analisadas geraram um desvio padrão muito baixo em relação à média gerando desta maneira uma confiabilidade ainda maior nos dados coletados. 
Pode-se constatar também que o Índice de Erro gerado para as médias foi muito pequeno, o que nos garantiu a confiabilidade dos dados mensurados.

Com a análise dos Intervalos de Confiança, considerando o nível de $95 \%$ de probabilidade para as estruturas mensuradas. Com essa análise percebemos que todas as médias geradas, estão muito próximas dos limites superiores e inferiores, caracterizando um padrão para essas estruturas.

Com relação à análise de variância para as estruturas mensuradas em relação às porções e aos lados verificou-se efeito significativo, ou seja, resultados expressivos, apenas para a estrutura ligamento flexor digital profundo, mensuração de espessura (PROFLG), em relação à variável porção, talvez devido à própria anatomia, uma vez que o tendão flexor digital profundo, após a região da articulação metacarpofalangeana aumenta de espessura e na porção distal da primeira falange ele se desloca passando acima do tendão flexor digital superficial, como verificado na dissecação. E para a estrutura cápsula articular, segmento palmar (CAPTR) na porção lado, devido talvez a não padronização da faixa etária e função dos animais que foram coletadas das peças.

Com relação à análise de variância em relação às porções distais e aos lados não foram encontrados significantes para nenhuma análise. Já nas estimativas de correlação para a porção proximal, verificou-se que as estimativas de correlação foram baixas para a grande maioria das estruturas avaliadas. O que mostra que os dados apresentados não podem ser considerados válidos, para uma análise de correlação, nem para a aplicação na rotina do médico veterinário, mesmo para as estruturas que apresentaram uma correlação moderadamente alta, não podendo ser considerado válido para criar 
um parâmetro de correlação, uma vez que foram resultados que não apresentaram uma expressividade alta.

Já para as porções distais pode-se também dizer que as estimativas de correlações foram baixas para a grande maioria das estruturas avaliadas. Para as estruturas que apresentaram correlações altas, pode-se dizer que as mesmas estão relacionadas principalmente a anatomia. Uma vez que as mesmas estão diretamente ligadas. 


\section{CONCLUSÕES}

Após ter feito a revisão literária, a parte experimental e as análises estatísticas, concluímos que:

A criação de um padrão para as estruturas mensuradas foi estatisticamente possível.

Animais sem sintomatologia clínica podem apresentar lesões nessa região articular.

A Cápsula Articular foi a que mais apresentou variações.

A correlação dos dados não foi estatisticamente significante.

A falta de padronização de idade, raça e função das peças coletadas nos prejudicou no momento de interpretar os resultados obtidos através da análise estatística.

Após as análises estatísticas se tornou possível dizer que os dados são considerados medidas relativas, uma vez que as mesmas se mostraram estatisticamente viáveis, gerando uma padronização confiável.

Para a análise de correlação se tornar válida é necessário que o "n" seja maior, e que as padronizações de idade, raça e função entrem na análise. 


\section{REFERÊNCIAS}

BLEVINS, W. E.; WIDMER, W. R., Radiology in racetrack practice. The Veterinary Clinics of North America: Equine Practice, v.6, n:1, 1990. p. 3161.

BOGERT, V. D. A. J., Computer simulation of locomotion in the horse: 1998. 151p. (graad van doctor) - Rijksuneversiteit Utrecht. 1989.

BORGES, E. M.; CANOLA, J.C.; MACHADO, M.R.F.; Estudo morfológico e radiológico sobre a comunicação entre a articulação interfalangeana distal e a bolsa do osso navicular em eqüinos (Equus caballus, L. 1758), Brazilian Journal Veterinary Reserch. Animal Science, v. 38, n: 5. 2001b. p. 220-223.

BORGES, E. M.; CANOLA, J.C.; MACHADO, M.R.F.; Estudo morfológico e radiológico sobre a comunicação entre a articulação interfalangeana distal e a bolsa do osso navicular em peças anatômicas de eqüinos (Equus caballus, L. 1758), Brazilian Journal Veterinary Reserch. Animal Science, v. 38, n: 6. 2001a. p. 258-262.

BOWMAN, K. F.; LEITCH, M.; NUNAMAKER, D., M., FACKELMAN, G., E.; TATE JR, L., P.; PARK M., I.; BOLES C., L.; RAKER C., W.; Complications during treatment of traumatic disruption of the suspensory apparatus in thoroughbred horses; Journal of American Veterinary Medical Association, v. 184, p. 706-715, 1984.

BRADLEY, O., C.: The Topographical anatomy of the limbs of the horse, Edinburgh: W. Green \& Son, Limited, 1920, 172 p.

BRAMLAGE, L. R.: Osteochondrosis - Related bone cysts, Annual Convention Proceedings. American Association of Equine Practitioners, v. 39, p. $83-85,1993$.

DENOIX, J. M.; JACOT, S.; BOUSSEAU, B.; PERROT, P., Ultrasonographic anatomy of the dorsal and abaxial aspects of the equine fetlock. Equine Veterinary Journal, v. 28, n. 1, p. 54-62, 1996.

DYCE, K. M.; SACK W. O.; WENSING C. J. G., Tratado de anatomia veterinária, 2. ed., Rio de Janeiro: Koogan, 1997. 663 p. 
DYCE, K. M.; SACK, W. O.; WENSING, C. J. G., Tratado de anatomia veterinária, $3^{a}$ ed., Rio de Janeiro: Elsevier, 2004. 663p.

ELIZIANO, E. L., Estudo comparativo entre os exames radiográfico e artroscópico da articulação metacarpofalangeana de eqüinos puro sangue inglês submetidos a treinamento para corrida. 2001. Tese (Mestrado em Cirurgia) - Faculdade de Medicina Veterinária e Zootecnia, Universidade de São Paulo, São Paulo, 2001.

FERRARO, G. L., Lameness diagnosis and treatment in thoroughbred racehorse. The Veterinary Clinics of North America: Equine Practice, v. 6, n: 1, p. 66-74, 1990.

FRACCAROLI, J. L., Biomecânica (Analise dos movimentos), São Paulo, Manole, 1977. 254 p.

FRETZ, P. B.; BARBER, S. M.; BAILEY, J. V.; McKENZIE, N., T., Manageament of proximal sesamoid bone fractures in the horse; Journal of the American Veterinarian Medical Association. v. 185. n. 3. 1984. p. 282-284.

GETTY, R.; SISSON / GROSSMAN: Anatomia dos animais domésticos. 5 ed. Rio de Janeiro, Guanabara Koogan, 1986. p. 328-336.

HOGAN, P.; MCILWRAITH, C. W.; HONNAS, C. M.; WATKINS, J. P.; BRAMLAGE, L. R.: Surgical treatment of subchondral cystic lesions of the third metacarpal bone: results in 15 horses (1986- 1994). Equine Veterinary Journal, v. 29, n: 6, p. 477-482, 1997.

KÖNIG, H. E.: LIEBICH, H. G., Anatomia dos animais domésticos. São Paulo: Artmed, 2002. v. 1291 p.

MACORIS, D. G.; BERTONE, A., Intra-articular pressure profiles of the cadaveric equine fetlock joint in motion, Equine Veterinary Journal, v. 33, n: 2, 2001. p. 184-190.

MORAES, J. R. E.; FERRARO, G. C.; SHIMANO, A. C.; BUENO DE CAMARGO, M. H.; MORAES F. R., Propriedades mecânicas de três padrões de sutura no reparo de tendão do músculo flexor profundo do 
dedo em eqüinos; Brazilian Journal of Veterinary Reserch Animal Science, v. 39, n: 2, 2002. p. 97-102.

MURPHY, D. J.; NIXON, A. J., Arthroscopic laser extirpation of metacarpophalangeal synovial pad proliferation in eleven horses, Equine Veterinary Journal, v. 33, n: 3, p. 296-301, 2001.

MUYBRIDGE, E.: Animals in motion. New York: Dover Publications, 1957. p. 19-27.

NICKEL, R.; SCHUMMER, A.; SEIFERLE, E.; FREWEIN, J.; WILKENS, H.; WILLE, K. H., The Locomotor system of the domestic mammals, Berlin Hamburg: Velag Paul Parey, 1986. p. 169-172; 188-189; 197-199.

O'BRIEN, T. R.; HORNOF, W. J.; MEAGHER, D. M., Radiographic detection and characterization of palmar lesions in the equine fetlock join - Journal American Veterinarian Medical Association. v. 178, n: 3, 1981. p. 231-237.

POOL, R. R.; MEAGHER, D. M., Pathologic findings and pathogenesis of racetrack injuries. The Veterinary Clinics of North America: Equine Practice, v. 6, n:1, 1990. p. 1-11.

PROVASI, A., Achados radiográficos nos ossos: terceira falange, sesamóide distal, terceiro metacarpiano, primeira falange e sesamóides proximais, dos membros anteriores de cavalos de corrida assintomáticos da raça puro sangue inglês (PSI). 2001. Tese (mestrado), Faculdade de Medicina Veterinária e Zootecnia, Universidade de São Paulo, São Paulo, 2001.

RICHARDSON, D. W.; NUNAMAKER, D.; SIGAFOOS, R. D., Use of an external skeletal fixation device and bone graft for arthrodesis of the metacarpophalangeal joint in horses - Journal American Veterinarian Association, v. 191, n: 3, 1987. p.316-321

RIEMERSMA, D. J., Biomechanics of the digital tendons in the equine hindleg. 1986. 104p. (graad van doctor) - Rijksuniversiteit te Utrecht. 1986.

ROSS, M. W.; DYSON, S. J., Diagnosis and management of lameness in the horse, St. Louis, Missouri: Saunders, 2003. p. 348-362. 
SANDE, R. D., The Metacarpophalangeal (Metatarsophalangeal) articulation. in: THRALL, D. E., Textbook of veterinary diagnostic radiology. 2. ed. Philadelphia: W. B. Saunders, 1994. p.181-189.

Statistical Analysis System, SAS. USER'S GUIDE: basic and statistic. Cary: SAS, 1995. $1686 \mathrm{p}$.

SCHALLER, O., Nomenclatura anatômica veterinária ilustrada: Editora Manole Ltda, 1999.

SOUTHWOOD, L. L.; McILWRAITH, W., Arthroscopic removal of fracture fragments involving a portion of the base of the proximal sesamoid bone in horses: 26 cases (1984- 1997); Journal of American Veterinarian Medical Association. v. 217, n: 2, 2000. p. 236-240.

STASHAK, T. S.; Diagnosis of lameness. in: STASHAK, T. S. Adam's lameness in horse. 4. ed. Philadelphia: Lea \& Febiger, 1987. p. 100-151; 486785

STEYN, P. F.; SCHMITZ, D.; WATKINS, J.; HOFFMAN, J., The Sonographic diagnosis of chronic proliferative synovits in the metacarpophalangeal joints of a horse - Veterinary Radiology, v. 30, n: 3, 1989. p. 125-127.

WEAVER, J. C. B.; STOVER, S. M.; O'BRIEN, T. R., Radiographic anatomy of soft tissue attachments in the equine metacarpophalangeal and proximal phalangeal region, Equine Veterinary Journal, v.24, n: 4, 1992. p. 310-315. 